\title{
A Study of Vehicular Propulsion Systems
}

by

Imran Lodhi

\author{
A project \\ presented to Ryerson University \\ in partial fulfillment of the \\ requirement of the degree of \\ Master of Engineering \\ in the Program of \\ Mechanical Engineering
}

PROPERTY OF

RYFPISON LNIVERSITY LIBRARY

Toronto, Ontario, Canada 2003

(C) (Imran Lodhi) 2003 
UMI Number: EC53448

\section{INFORMATION TO USERS}

The quality of this reproduction is dependent upon the quality of the copy submitted. Broken or indistinct print, colored or poor quality illustrations and photographs, print bleed-through, substandard margins, and improper alignment can adversely affect reproduction.

In the unlikely event that the author did not send a complete manuscript and there are missing pages, these will be noted. Also, if unauthorized copyright material had to be removed, a note will indicate the deletion.

\section{UMI}

UMI Microform EC53448

Copyright 2009 by ProQuest LLC

All rights reserved. This microform edition is protected against unauthorized copying under Title 17, United States Code.

ProQuest LLC

789 East Eisenhower Parkway

P.O. Box 1346

Ann Arbor, MI 48106-1346 


\section{Author's declaration}

I hereby declare that I am the sole author of this project report.

I authorize Ryerson University to lend this thesis to other institutions or individuals for the purpose of scholarly research.

Imran-ur-Rehman Lodhi

I further authorize Ryerson University to reproduce this project report by photocopying or by other means, in total or in part, at the request of other institutions or individuals for the purpose of scholarly research.

Imran-ur-Rehman Lodhi 


\section{Borrower Page}

Ryerson Polytechnic University requires the signatures of all persons using or photocopying this project.

Please sign below, and give address and date.

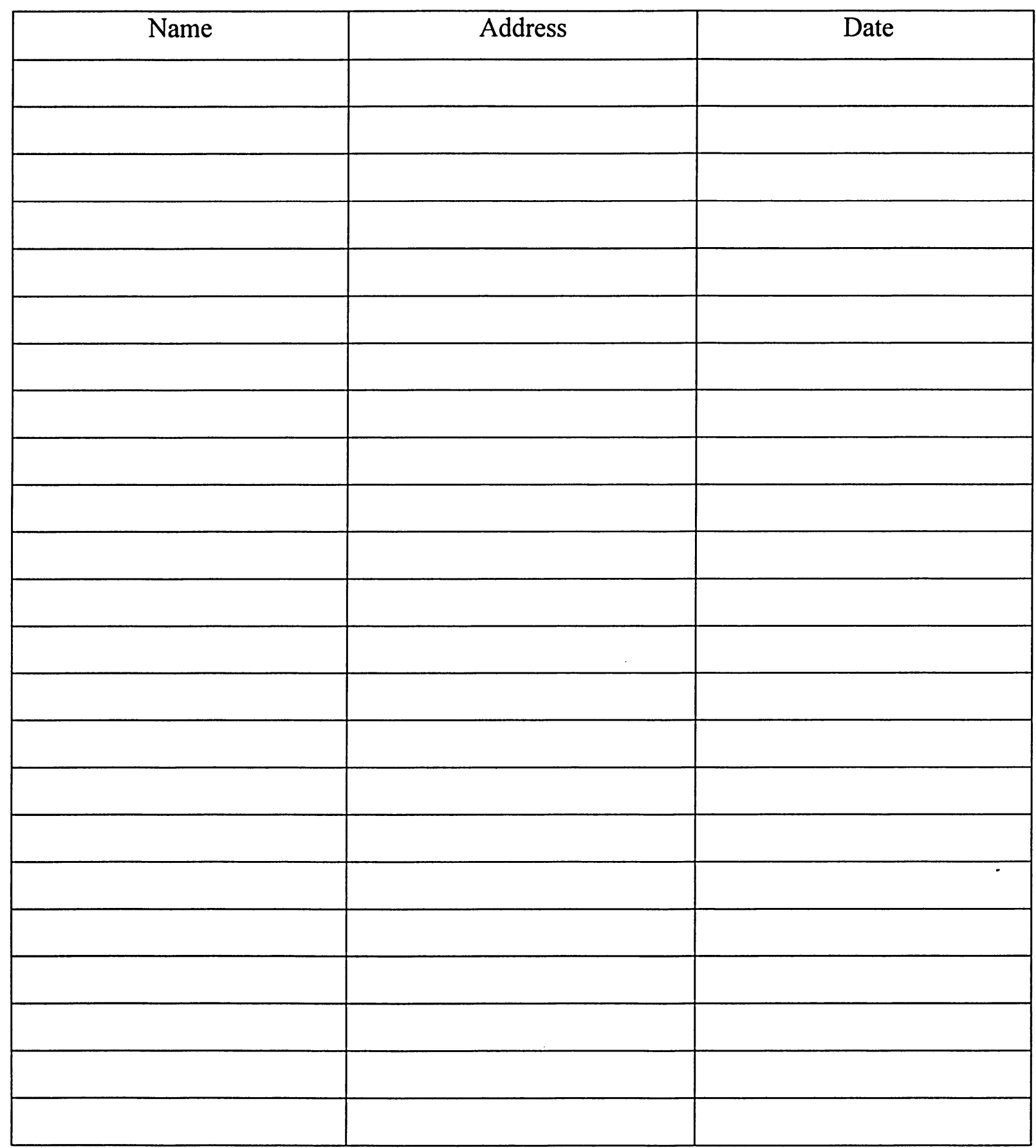




\section{A Study of Vehicular Propulsion Systems}

\section{Abstract}

The world is suffering from a severe oil crisis. Half of the oil present beneath the surface of the earth has been consumed and remaining oil in the oil reserves will be used up in the near future. Consumption of two-thirds of oil produced in transportation indicates the extent of our oil dependency. On the other hand emissions of pollutants like $\mathrm{CO}, \mathrm{HC}$, and $\mathrm{NO}_{\mathrm{x}}$ are a health hazard and cause serious damage to the environment. If the consumption of oil would continue at present rapidity, and new fuels and other vehicular power systems were not developed, the world would face a disastrous situation. There is an urgent need for successful development in new technologies to replace gasoline/ diesel dependent internal combustion engine (ICE).

The aim of this study is to find both a short-term and an unending solution to environmental damage caused by vehicles, and the current oil crisis. In this report different vehicular power systems i.e. internal combustion engine, fuel cell, hybrid system and electric system are studied with regards to technical, environmental and cost issues to find a solution to the oil crisis and environmental damage.

It is concluded that an interim solution would be a hybrid system vehicle that has a PEM fuel cell and a battery. However, the permanent solution to the problem is a hybrid vehicle that uses a reformer-independent PEM fuel cell and a battery, and is supplied with pure hydrogen onboard. The hydrogen to be used in the hybrid vehicle must be obtained from electrolysis of water, using electricity generated by solar, wind or hydro resources. 


\section{Acknowledgements}

This project report has been completed with the blessings of Almighty Allah (God).

I would like to especially thank Dr. Ziad Saghir, Professor at Ryerson University Toronto Canada, whose great kindness, enormous vision, immense knowledge, and excellent guidance contributed to the successful completion of this project.

Prayers of my parents, wife, and encouragement of my friend, Muhammad Adrees made this project possible for me. 


\section{Table of Contents}

Chapter

Page

1 Introduction 1

2 The working of an Internal Combustion Engine 2

3 Construction of Internal Combustion Engine (ICE) 8

$\begin{array}{lll}3.1 & \text { Power system } & 8\end{array}$

$\begin{array}{lll}3.2 & \text { Oil system } & 9\end{array}$

$\begin{array}{lll}3.3 & \text { Reciprocating to rotary system } & 10\end{array}$

$\begin{array}{lll}3.4 & \text { Ignition system } & 15\end{array}$

$\begin{array}{lll}3.5 & \text { Fuel injection and exhaust system } & 17\end{array}$

$\begin{array}{lll}3.6 & 19\end{array}$

$\begin{array}{lll}3.7 & \text { Fuel pump } & 20\end{array}$

$\begin{array}{lll}3.8 & \text { Fuel tank } & 21\end{array}$

$\begin{array}{lll}3.9 & \text { Fuel filter } & 21\end{array}$

$\begin{array}{lll}3.10 & \text { Fuel gauges } & 22\end{array}$

3.11 Combustion chamber 23

3.12 Supercharger 23

$\begin{array}{lll}3.13 & \text { Turbocharger } & 24\end{array}$

3.14 Breathers 25

3.15 Vacuum pump 25

3.16 Air pump 26

3.17 Air cleaner 26

$3.18 \quad$ Vibration damper 26

3.19 Timing belts 27

$\begin{array}{lll}3.20 & \text { Metering rod } & 27\end{array}$

$3.21 \quad$ Radiator 28

$3.22 \quad$ Cooling fans 28

4 Fuel cell 30

4.1 Working of a fuel cell 31

$4.2 \quad$ Fuel cell systems 33 
4.3 Types of fuel cells 36

4.3.1 Phosphoric Acid Fuel Cell (PAFC) 36

4.3.2 Proton Exchange Membrane Fuel Cell (PEMFC) 37

4.3.3 Molten Carbonate Fuel Cell (MCFC) 38

4.3.4 Solid Oxide Fuel Cell (SOFC) 39

$\begin{array}{lll}\text { 4.3.5 } & \text { Alkaline Fuel Cell (AFC) }\end{array}$

4.3.6 Direct Methanol Fuel Cell (DMFC) · 40

5 Fuel Cell - A better choice 41

$5.1 \quad$ Importance of PEM Fuel Cell 42

5.2 Problems with PEM Fuel Cell 43

5.3 The best fuel: Hydrogen 44

6 Hybrid system 46

$\begin{array}{lll}6.1 & \text { Electric motor } & 46\end{array}$

$\begin{array}{lll}6.2 & \text { Generator } & 47\end{array}$

$\begin{array}{lll}6.3 & \text { Gasoline engine } & 47\end{array}$

$\begin{array}{lll}6.4 & \text { Fuel tank } & 47\end{array}$

$\begin{array}{lll}6.5 & \text { Batteries } & 48\end{array}$

$\begin{array}{lll}6.6 & \text { Transmission } & 48\end{array}$

$\begin{array}{lll}6.7 & \text { Hybrid configuration } & 48\end{array}$

6.8 Hybrid electric system's features 50

7 Electric propulsion system $\quad 52$

8 Discussion and conclusion $\quad 56$ 


\section{List of Tables}

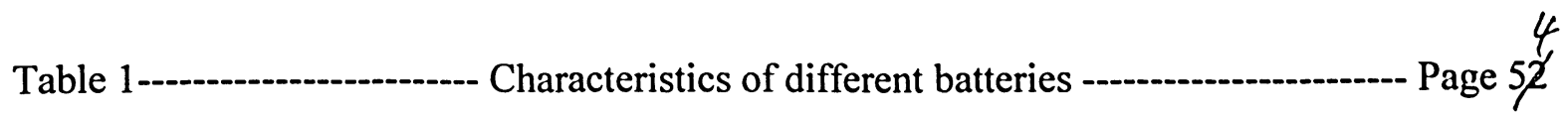




\section{List of figures}

Figure 1

Figure 2

Figure 3

Figure 4

Figure 5

Figure 6

Figure 7

Figure 8

Figure 9

Figure 10

Figure 11

Figure 12

Figure 13
Use of ICE in series hybrid vehicle

Use of ICE in parallel hybrid vehicle

PV diagram

TS diagram

PV diagram

TS diagram

An illustration of catalyst with lumda sensor

Fuel cell basics

Fuel cell system schematic

Series hybrid vehicle

Parallel hybrid vehicle

One motor drive for an electric vehicle

M-4 technology for an electric vehicle
Page 3

Page 3

Page 7

Page 7

Page 7

Page 7

Page 19

Page 33

Page 34

Page 48

Page 49

Page 52

Page 51 


\section{Chapter 1: Introduction}

The oil crisis in the world is getting worse. In the past 200 years half of the oil present beneath the surface of the earth has been consumed and remaining oil in the oil reserves will be used up in the next 40 years. Two-thirds of oil produced is used in transportation, which indicates our strong reliance. Vehicular emissions of pollutants like $\mathrm{CO}, \mathrm{HC}$, and $\mathrm{NO}_{\mathrm{x}}$ are health hazard and cause serious damage to the environment. If the consumption of oil continues at its present pace and new fuels and other vehicular power systems were not developed, the world would face a catastrophic situation. There is an urgent need for successful development in new technologies to replace gasoline/ diesel dependent internal combustion engine (ICE). In transportation, research is being carried out on different vehicular power systems like internal combustion engine, fuel cell, hybrid and electric power systems. There is a need to ascertain which vehicular power system should be developed on a priority basis.

The aim of this study is to find an interim and permanent solution to environmental damage caused by vehicles, and the oil crisis. In this report different power systems i.e. internal combustion engine, fuel cell, hybrid system and electric system are studied with regards to technical, environmental and cost issues. Oil- reliant ICE is the biggest cause of pollution on the earth and it also damages the environment. Due to availability, easy transportation and storage of oil, and due to presence of highly skilled labor, manufacturing experts, the ICE is today's only choice but not the only choice of the future. Fuel cells are quiet, clean and unlike a battery they operate as long as fuel is supplied to them. They produce zero emissions of pollutants. The emission of pollutants is produced when the fuel is reformed to obtain pure hydrogen through a reformer. Electric vehicles are useful for limited use and range. Hybrid systems are acceptable at present as they offer long term and short term solutions. Different hybrid systems are present with different configurations. 


\section{Chapter 2: The Working of An Internal Combustion Engine}

Internal combustion engines are reliable, efficient, inexpensive, and are relatively easy to operate.

The efficiency of an internal combustion engine can be improved by taking the following into account:

a The vehicle faces air resistance when moving and it increases with the speed of vehicle or the speed of wind. In such situations the engine has to produce more power to drag a vehicle. If air dynamic shapes are introduced the consumption of fuel would be less and the efficiency of the engine will increase.

- Reducing the rolling resistance can also increase efficiency. In this case the study of roads and tire is emphasized.

B. Johansson and M. ${ }^{\circ} \mathrm{Ahman}$ [1] referred to some of the studies, which state that a $40 \%$ reduction in energy use by an engine is possible.

The efficiency of an engine could also be improved through the following [1]:

口 Valve timing

口 Shut off during idling

口 Higher compression ratio

The internal combustion engines are so much in demand that in spite of all its unwanted polluting emissions they are now considered for use in hybrid vehicles. In a hybrid vehicle the internal combustion engine takes over drive from the electric drive train, when the battery is discharged. It also produces electricity through the generator to be supplied to either directly to the motor or to a battery. Addition of an ICE-alternator unit to an electric vehicle results in a hybrid electric vehicle. An electric motor and a battery are responsible for providing traction power for the drive train in case of series hybrid vehicle. The electric motor and the battery are added to the conventional drive train to form a parallel hybrid vehicle. They assist the engine during acceleration and accept energy produced by braking. The use of the ICE in hybrid is shown as under in figure 1 and 2: 


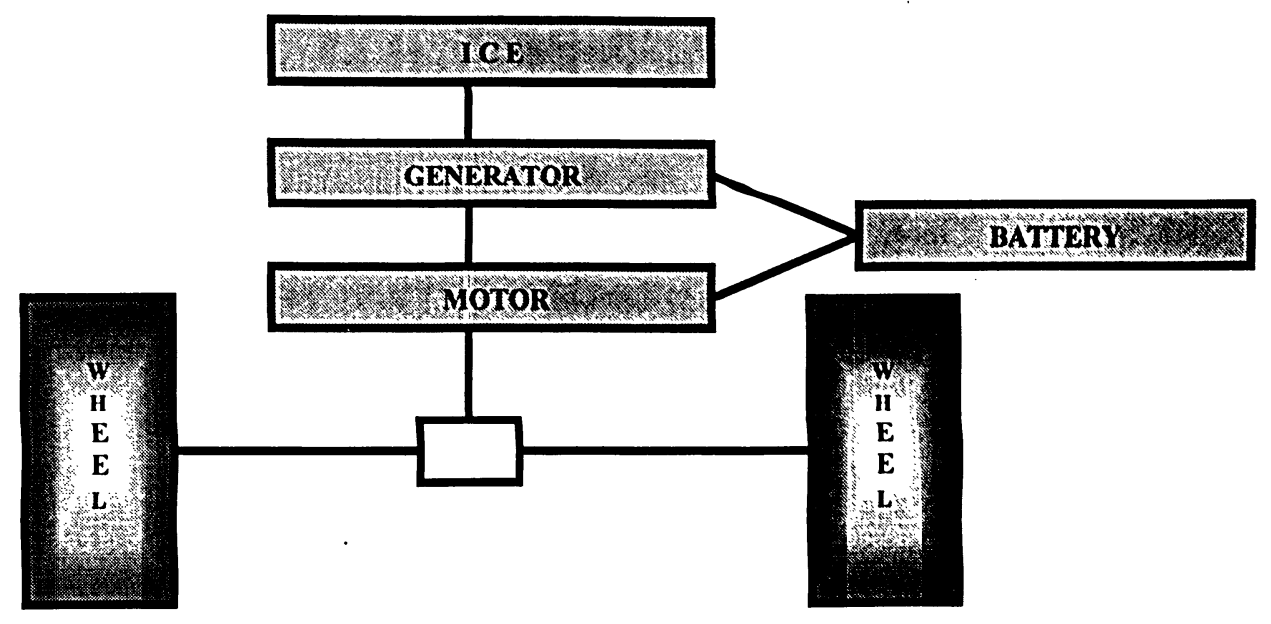

Figure 1: Use of ICE in series hybrid vehicle [2]

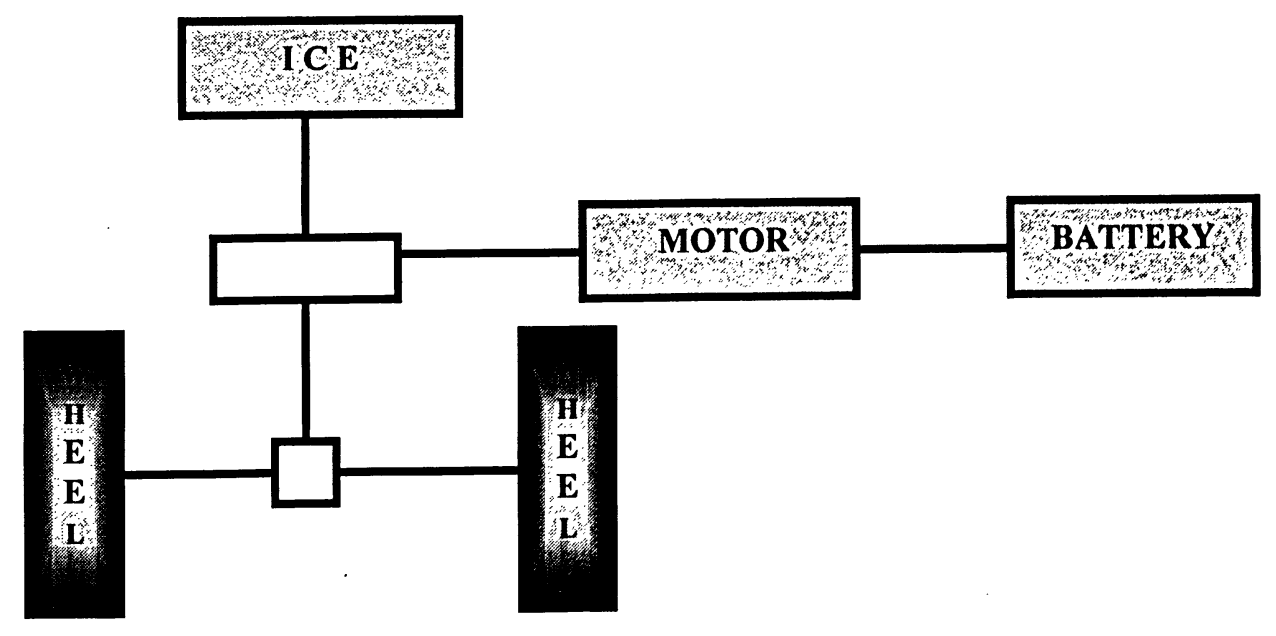

Figures 2: Use of ICE in parallel hybrid vehicle [2] 
The engines, which are in use today, are far better than the engines of old days as far as emissions are considered. Now the engines emit far less pollutants. A study shows that 350 million vehicles were on road world wide in 1995, which produced about 250 million tons of pollutants excluding carbon dioxide. For the year of 2010, it is estimated that there would be about 700 millions vehicles which would produce about 20 million tons of pollutants [3].

Burning of fuel causes conversion of chemical energy into mechanical energy in an internal combustion engine. When a spark in a combustion chamber ignites the fuel-air mixture, chemical energy is released. The gas produced in this reaction expands to force a piston down the cylinder in a power stroke.

The basic components for a combustion cycle in a four-stroke engine are:

口 The combustion chamber

口 Piston

口 Intake port

Outlet port or exhaust port.

The piston reciprocates inside a cylinder. The exhaust and intake ports open and close during various stages of a cycle. The movement of the piston up or down the cylinder makes up one stroke of a four-stroke cycle.

The crankshaft converts the linear motion of the piston into rotary motion. The flywheel helps to smooth out the linear movement of the piston.

Each movement of a piston up or down a cylinder is one stroke of the four-stroke combustion cycle. Most modern internal combustion engines use the four-stroke cycle. The four stroke cycle consists of an induction stroke where air and fuel are taken into the cylinder as the piston moves downwards, a compression stroke where the air and fuel are compressed by the upstroke of the piston, the ignition or power stroke where the compressed mixture is ignited and the expansion forces the piston downwards, and an exhaust stroke where the waste gases are forced out of the cylinder. The intake and outlet ports open and close to allow air to be drawn into the cylinder and exhaust gases to be expelled.

During the intake stroke the inlet valve opens at the top of the cylinder, as the piston moves down air and fuel are drawn into the cylinder. As the piston reaches its lowest position the inlet valve closes and the piston travels upwards compressing the air-fuel mixture. As the piston reaches its highest position at maximum compression a spark ignites the mixture causing a 
rapid expansion of gas raising the pressure in the cylinder and forcing the piston downwards. When the cylinder reaches its lowest position the outlet port opens and as the piston rises up the cylinder the exhaust gases are forced out. The valves that open and close the ports are used to keep the ports close perfectly. Rotating cams and pushrods, which are driven by a camshaft, which in turn is timed and driven from crankshaft, operates the valves.

The intake stroke of the combustion cycle starts when the piston travels down the cylinder and at this time the intake port remains open. A mixture of air and fuel are drawn into the cylinder. Both the air-fuel ratio and the quality of the mixture are important for an efficient combustion process. There are two methods of mixing air and fuel in a combustion engine:

Carbureted method

口 Electronic fuel injection method

In a carbureted engine, during the intake stroke of the piston a vacuum is created in the inlet manifold. In a multi cylinder engine the vacuum is constant. The carburetor is located at the top of the manifold and the vacuum created in the manifold draws air through it. The carburetor has a small fuel chamber that is supplied with fuel from the fuel tank by a pump. The fuel passes through the carburetor to small fuel jets positioned in the airflow. The fuel vaporizes in the airflow and passes through the manifold and into cylinders on their intake stroke.

Electronic fuel injection systems spray fuel at high pressure either directly into the combustion chamber or into the intake port of the cylinder during the intake stroke. Using fuel injection enables improved control over the air-fuel mixture and reduces the power required to draw fuel from the jets.

Diesel engines use direct injection, which injects fuel directly into the combustion chamber during the compression stroke. The intake stroke of a diesel engine only draws air into the cylinder.

The compression stroke is the upward movement of the piston in the cylinder with the valves closed following the intake stroke. This upward motion compresses the fuel air mixture inside the combustion chamber raising the pressure.

The compression ratio is particularly important in compression-fired engines such as diesel engines. The fuel-air mixture and compression ratio is critical to avoid pre-ignition which is the abnormal ignition of fuel in the combustion chamber before the combustion stroke. In 
diesel engines the fuel is injected under high pressure towards the top of the compression stroke. The distribution of fuel before combustion is also important because it affects the efficiency of combustion.

Spark plugs are used to generate the spark, which ignites the compressed fuel and air mixture in the spark ignition engine. To generate the spark a high voltage of around twenty thousand volts is applied. The high voltage is generated when the low voltage supply is interrupted and the magnetic field breaks down generating a high voltage in the secondary winding, which has a much larger number of coils. The low voltage supply to the coil is controlled by the distributor, which also controls the spark plugs that the high voltage surge is sent to.

Compression ignition engines such as the diesel engine do not use spark plugs to ignite the airfuel mixture. When the piston reaches the top of the compression stroke the temperature and the pressure in the combustion chamber is sufficient to ignite the mixture. Controlled ignition in both spark ignition and diesel engines is essential for efficient combustion and to avoid uncontrolled combustion effects such as pre-ignition, auto-ignition and engine knock.

Exhaust gases are pushed out of the cylinder by the upward motion of the piston following the ignition stroke. The exhaust gases are passed into the exhaust manifold and sent into the exhaust pipe where they are released into the atmosphere. The exhaust system may contain a smoke box to trap the larger soot particles; it may also be fitted with a catalytic converter, which removes some of the harmful components from the exhaust gases.

The efficiency of the combustion process and the design of the engine determine the exhaust constituents. Exhaust gases contain oxygen, nitrogen, water vapors, carbon dioxide, carbon monoxide, hydrogen, nitrous oxides, particulates and unburned hydrocarbons.

In an Otto cycle the compression stroke (1-2) is adiabatic. Ignition of gas fuel mixture takes place rapidly at top of the compression stroke while the volume is constant (2-3). Expansion stroke is adiabatic. Isentropic expansion of gases takes place after the fuel mixture is ignited (3-4). In this part of the cycle the piston does positive work. Exhaust of the spent gases and the intake of a new fuel mixture into the cylinder take place at constant volume (4-1) as shown in the following figures 3 and 4 . 


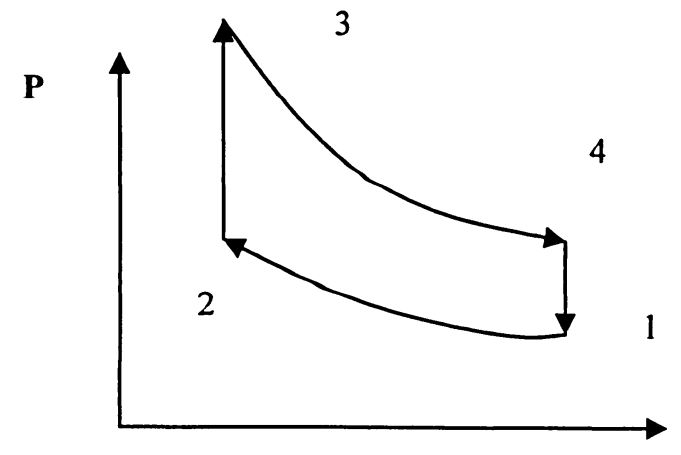

Figure 3: PV diagram

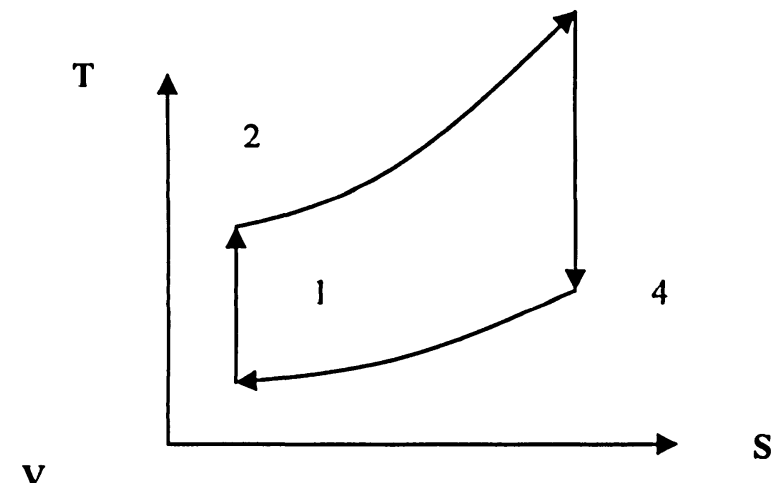

Figure 4: TS diagram

In a diesel cycle, compression stroke is adiabatic compression of air in the cylinder (1-2). Ignition of fuel mixture takes place at high temperature due to a large compression. Burning takes place while the pressure is constant (2-3). In expansion stroke, adiabatic and isentropic expansion of gases takes place. Piston does positive work in this part of the cycle (3-4). Exhaust of the spent gases and the intake of a new fuel mixture into the cylinder take place at constant volume (4-1) as shown in the following figures 5 and 6.

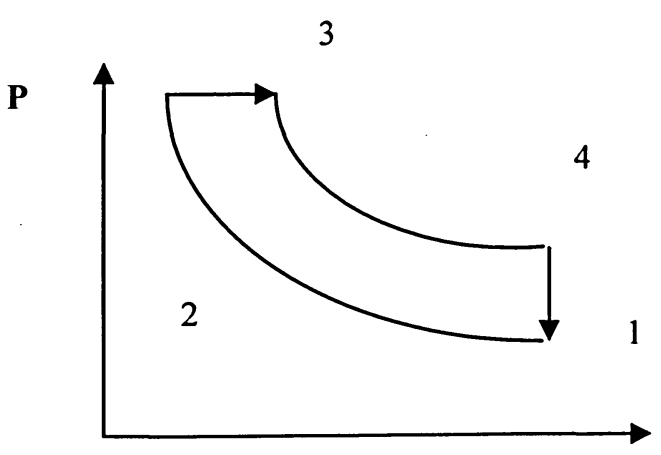

Figure 5: PV diagram

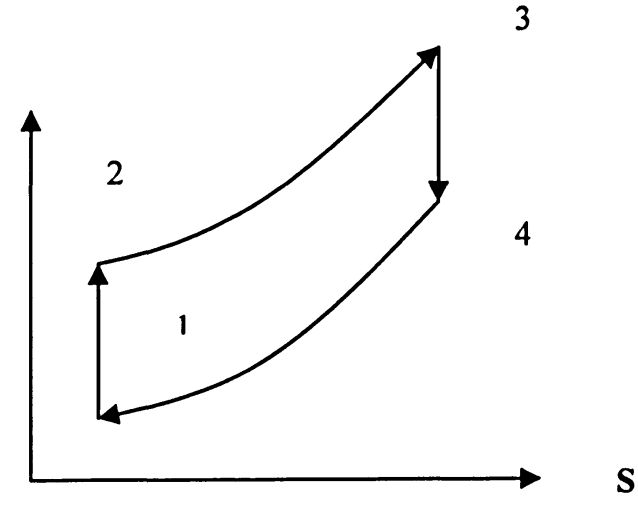

Figure 6: TS diagram 


\section{Chapter 3: Construction of Internal Combustion Engine}

ICE can be operated on alternate fuels like biodiesel, compressed natural gas, ethanol, methanol, and propane. The construction of an internal combustion engine is complicated as it operates different systems of a vehicle. The moving parts of the engine of a vehicle produce vibration and the emission of the engine contains pollutants that are dangerous for environment and health. A lot of research is being carried out for the improvement of internal combustion engine. Emissions are being controlled through the improvement of fuel and catalytic converter.

Three-way catalyst and computerized fuel injection contribute to significantly fewer pollutants. Manifold catalytic converter reduces the polluting emissions during the cold engine starts [4]. The engine has the following systems/ parts:

\subsection{Power system}

The piston converts the potential energy of the fuel, into the kinetic energy, which turns the crankshaft. The piston is a cylindrical shaped hollow part. It moves up and sown inside the engine's cylinder. It has grooves around its perimeter near the top where rings are placed. The piston fits in the cylinder. The piston rings are used to ensure airtight fit.

The piston requires four strokes to complete the cycle. The first is the intake stroke. This is a downward stroke to fill the cylinder with a fuel and air mixture. The second is an upward stroke to compress the mixture. Before the piston reaches its maximum height in te cylinder, the spark plug fires and ignites the fuel. This action causes the piston to make its third stroke. The third stroke is the power stroke. It is the stroke, which powers the engine. On the fourth stroke, the burnt gases are sent out through the exhaust system.

The piston is connected to connecting rod through a wrist pin. The connecting rod comes up through the bottom of the piston. The wrist pin is inserted into a hole of the piston, where it is attached to the connecting rod.

The material of a piston is aluminum, because it is light and a good heat conductor. Pistons perform several functions. Pistons transmit the driving force of combustion to the crankshaft. This causes the crankshaft to rotate. The piston head is the top surface against which the 
explosive force is exerted. It may be flat, concave, or any one of a great variety of shapes. These shapes control combustion. A narrow groove is cut into the piston above the top ring to serve as a heat dam to reduce the amount of heat reaching the top ring.

A cylinder has a round hole through the block, bored to receive a piston. All automobiles engines are water-cooled or air-cooled; four-cycle or two-cycle and have more than one cylinder. These multiple cylinders are arranged in-line, opposed, or in a V.

The cylinder head is the metal part of the engine and it encloses and covers the cylinder. The cylinder head contains combustion chambers, water jackets and valves. The head gasket seals the passages within the head-block connection, and seals the cylinders as well.

\subsection{Oil system}

The oil pump is used to force pressurized oil to the various parts of the engine. Gear and rotary pumps are the most common types of pumps. The gear pump consists of a driven spur gear and a driving gear that is attached to a shaft driven by the camshaft. The two gears are the same size and fit in the pump body. Oil is carried from the inlet to the delivery side of the pump by the opposite teeth of both gears where it is forced into the delivery pipe. It cannot flow back, because the space between the meshing gear teeth is too tight.

Oil seals are rubber and metal composite items. They are mounted at the end of shafts. They are used to keep fluids, such as oil, transmission fluid, and power steering fluid inside the object they are sealing. These seals flex to hold a tight fit around the shaft that comes out of the housing, and do not allow any fluid to pass. Oil seals are common points of leakage and can usually be replaced.

The engine oil dipstick is a long metal rod that goes into the oil sump. The purpose of the dipstick is to check how much oil in an engine is. The dipstick is held in a tube; the end or the tube extends into the oil sump. It has measurement markings on it. If it is pulled out the level of oil on the markings gives information about how munch oil is needed.

The oil filler cap is a plastic or metal cap. It allows adding oil when the dipstick indicated that oil is needed. Some engines have the crankcase vented through the filler cap. Oil, which is added through the filler, is passed down through openings in the head into the oil sump at the bottom of the engine. 
Oil filters are placed in the engine's oil system to strain dirt and abrasive materials out of the oil. The oil filter cannot remove things that dilute the oil, such as gasoline and acids. Modern engines use the full flow type of oil filters. With this type of filter, all of the oil passes through the filter before it reaches engine's moving parts. If a filter becomes clogged, a bypass valve allows oil to continue to reach the bearings. The most common type of oil filter is a cartridge type. Oil filters are disposable; at prescribed intervals, the filter are replaced and thrown away.

There are a variety of pathways for oil to be sent to moving parts of the engine. These pathways are designed to deliver the same pressure of fresh lubricating oil to all parts. If the pathways become clogged, the affected parts will lock together. This usually destroys parts that are not lubricated, and often ruins the entire engine. The oil passages are drilled into the connecting parts of the engine. The oil passages allow the highly mobile parts to have ample lubrication. Originating at the oil pump, they flow through all of the major components of the engine. In the case of pistons and rods, the passages are designed to open each time the holes in the crankshaft and rods align.

At the bottom of the crankcase is the container containing the oil of the engine. Usually constructed of thin steel, it collects the oil as it flows down from the sides of the crankcase. The pan is shaped into a deeper section, where the oil pump is located. At the bottom of the pan is the drain plug, which is used to drain the oil. The plug is often made with a magnet in it, which collects metal fragments from the oil.

\subsection{Reciprocating to rotary (motion) system}

The crankshaft converts reciprocating motion of pistons into a rotary motion. It provides the turning motion for the wheels. The crankshaft is usually either alloy steel or cast iron. The crankshaft is connected to the pistons by the connecting rods.

The crankshaft is held in place by a series of main bearings. The largest number of main bearings a crankshaft can have is one more than the number of cylinders, but it can have one less bearing than the number of cylinders. 
The bearings support the crankshaft. One bearing controls the forward-backward movement of the crankshaft. This bearing rubs against a ground surface of the main journal, and is called the thrust bearing.

The connecting rod links the piston to the crankshaft. The upper end has a hole in it for the piston wrist pin and the lower end, which is called big end, attaches to the crankshaft. Connecting rods are usually made of alloy steel. Some are made of aluminum.

Connecting rod bearings are inserts that fit into the connecting rod's lower end and ride on the journals of the crankshaft.

The valve-in-head engine has pushrods. Pushrods extend upward from the cam followers to rocker arms. Rocker arms are mounted on the cylinder head. The rocker arms contact the valve stems and transmit the motion produced by the cam profile to the valves. Clearance is maintained between the ends of the valve stems and the lifter mechanism to assure proper closing of the valves when the engine temperature changes. This is done by providing pushrod length adjustment or by the use of hydraulic lifters. Noisy and inconsistent valve operation can be eliminated with entirely mechanical valve lifter linkage. To achieve this the tappet clearance between the rocker arms and the valve stems is closely maintained at the specified value for the engine. Now hydraulic valve lifters are commonly used on automobile engines, and they eliminate the need for periodic adjustment of clearance.

The hydraulic lifter comprises a cam follower. The cam follower is moved up and down by contact with the cam profile. In inner bore the valve lifter is closely fitted and retained by a spring clip. The valve lifter is a cup closed at the top by a freely moving cylindrical plug. The cylindrical plug has a socket at the top to fit the lower end of the pushrod. This plug is pushed upward by a light spring that is merely capable of taking up the clearance between the valve stem and the rocker arm. A small hole is drilled in the bottom of the valve- lifter cup to admit lubricating oil. The oil enters the cam follower from the engine lubricating system through a passage into cylinder block. A small steel ball serves as a check valve to admit the oil into the valve-fitter cup but prevent its escape. When the clearance in the entire linkage between the cam profile and the valve stem is being taken up by the spring in the valve lifter, oil flows into the lifter chamber past the ball check. The oil is trapped to maintain this no clearance condition as the engine operates. Expansion or contraction of the valve linkage is compensated by oil seepage from the lifter to correct for expansion of parts and oil flow into the chamber if 
clearance tends to be produced between the pushrod and the lifter. Complete closure of the valve is then assured at all times without tappet noise.

The intake valve must be open while the piston is descending on the intake stroke of the piston. The exhaust valve must be open while the piston is rising on the exhaust stroke. The opening and closing of the two valves occurs at the appropriate top and bottom dead center points of the crankshaft. Te time required for the valves to open and close and the effects of high speed on the starting and stopping of the flow of the gases requires that for optimum performance the opening events occur before the crankshaft dead center positions and that the closing events be delayed until after dead center.

Inlet opening, inlet closing, exhaust opening, and exhaust closing, are accordingly displaced appreciably from the top and bottom dead centers. Opening events are earlier and closing events are later to permit ramps to be incorporated in the cam profiles to allow gradual initial opening and final closing to avoid slamming of the valves. Ramps are provided to start the lift gradually. They also slow the valve down before it contacts its seat.

Overhead valves are used for two purposes:

a Suction of fuel

a Exhaust of gases

In an overhead valve engine, the valves are mounted in the cylinder head, above the combustion chamber. Usually this type of engine has the camshaft mounted in the cylinder block, and the valves are opened and closed by push rods. Some other valves are:

$\begin{array}{ll}\text { ㅁ } & \text { Choke valve } \\ \text { } & \text { Throttle valve } \\ \text { } & \text { PCV valve }\end{array}$

Chokes perform the fuel mixture adjustments necessary to start a cold engine. When the fuel air mixture is too cold, the engine cannot start properly, or will stall out periodically. The choke when engaged caused the fuel air mixture to be increased or enriched. The choke is a special valve placed at the mouth of the carburetor so that it partially blocks off the entering air. When the choke plate closes, the vacuum below it increases, drawing more fuel from the fuel bowl. The rich fuel mixture burns even at lower temperatures, allowing the engine to warm up. 
The manual choke is a knob on the dash, usually the push pull type, which extends from the choke on the carburetor to the instrument pane. A driver closes the choke when starting the engine. The main thing to know about a manual choke is to push it back in when the engine has reached normal operating temperature. The trouble with the manual choke is that the driver often forgets to open it fully. This results in rich fuel mixture, which causes carbon to form in the combustion chambers and on the spark plugs. To correct this problem, the automatic choke was developed.

The automatic choke relies on engine heat. The choke valve is run by a thermostat, which is controlled by exhaust heat. When the engine is cold, the valve will be closed for starting. As the engine warms, the exhaust heat will gradually open the choke valve. An automatic choke depends on a thermostatic coil spring unwinding as heat is supplied. As the engine warms up, manifold heat is transmitted to the choke housing. The heat causes the bimetal spring to relax, opening the valve.

All gasoline engines have a throttle valve to control the volume of intake air. The amount of fuel and air that goes into the combustion chamber regulates the engine speed and therefore engine power. The throttle valve is linked to accelerator. The throttle valve is a butterfly valve that usually consists of a disc mounted on a spindle. The disc is roughly circular, and it has the same diameter as the main air passage in the throat or venturi.

Several gases and vapors are formed during the process of combustion. Many of them are quite corrosive. Some of these gases get past the piston rings and into the crankcase. If left in the crankcase, these substances would cause all kinds of rusting, corrosion, and formation of sludge. So these unwanted gases have to be removed. The PCV system uses a hose connected between the engine and the intake manifold to draw these gases out of the engine's crankcase and back into the cylinders to burn with the regular fuel. To keep these gases from going into the manifold and upsetting the required air-fuel ratio, the PCV valve is used. The PCV valve controls the release of crankcase gases and vapors to the intake manifold. The valve is kept closed by spring action when the engine is at rest. When the engine is running normally, the low vacuum it creates allows the valve to open and release crankcase vapors and gases into the intake manifold for burning. If the engine is idling or slowing down, the vacuum level rises and pulls the valve plunger into the valve opening. This partially blocks off the opening so that only a small amount of vapors and gases can be drawn into the intake manifold. One feature of 
the PCV valve is its behavior in the event of a backfire. If vehicle backfires in the manifold, the pressure makes the spring close valve completely. When valve is closed, there is no chance that the flame can move into the crankcase and thus explosion can be avoided.

Follower is a part used to provide a repetitive straight line or back and forth motion to a second part. Cams are used to open and close the inlet and exhaust valves of a car engine. Complex cam shapes may be required to produce a desired motion.

There are three types of cams:

$\begin{array}{ll}\text { } & \text { Disc cam } \\ \square & \text { Cylinder cam } \\ \square & \text { Translation cam }\end{array}$

The most common is disc cam. The cam profile is cut from a disc mounted on a rotating shaft. The follower can be a flat plate moving vertically in a straight line, or it can be a roller or knife-edge that moves in a straight line or is pivoted. The follower is usually spring loaded to retain contact with the cam. The second type of cam commonly used is the cylinder cam. The third type is the translation cam in which the required profile that defines the motion is cut into a flat plate that moves back and forth. The motion to the follower can be changed easily in order to obtain a desired sequence by altering the shape of the cam profile.

Some engines have the camshaft mounted above the cylinder head instead of inside the block. This arrangement has the advantage of eliminating the added weight of the rocker arms and push rods. This weight can sometimes make the valves float when vehicle is moving at high speeds. The camshaft lobe rubbing directly on the rocker operates the rocker arm setup. Stem to rocker clearance is maintained with a hydraulic valve lash adjuster for zero clearance.

The double overhead camshaft is the same as the overhead camshaft, except that there are two camshafts instead of one.

The purpose of carburetion is to supply and meter the mixture of fuel vapor and air in relation to the load and speed of the engine. Because of engine temperature, speed, and load, perfect carburetion is very hard to obtain.

The carburetor supplies a small amount of a very rich fuel mixture when the engine is cold and running at idle. With the throttle plate closed and air from the air cleaner limited by the closed choke plate, engine suction is amplified at the idle-circuit nozzle. This vacuum draws a thick spray of gasoline through the nozzle from the full float bowl, whose fuel line is closed by the 
float-supported needle valve. More fuel is provided when the gas pedal is depressed for acceleration. The pedal linkage opens the throttle plate and the choke plate to send air rushing through the barrel. The linkage also depresses the accelerator pump, providing added gasoline through the accelerator-circuit nozzle. As air passes through the narrow center of the barrel, called the venturi, it produces suction that draws spray from the cruising-circuit nozzle. The float-bowl level drops and causes the float to tip and the needle valve to open the fuel line. The difference of low pressure within the cylinder and atmospheric pressure outside of the carburetor causes air and fuel to flow into the cylinder from the carburetor.

\subsection{Ignition system}

The ignition distributor makes and breaks the primary ignition circuit. It also distributes high tension current to the proper spark plug at the correct time. The distributor is driven at one half-crankshaft speed on four-cycle engines. The camshaft drives it. Distributor construction varies, but the standard model is made of a housing into which the distributor shaft and centrifugal weight assembly are fitted with bearings. In most cases, these bearings are bronze bushings.

In standard ignition, the contact set is attached to the movable breaker plate. A vacuum advance unit attached to the distributor housing is mounted under the breaker plate. The rotor covers the centrifugal advance mechanism, which consists of a cam actuated by two centrifugal weights. As the breaker rotates, each lobe passes under the rubbing block, causing the breaker points to open. Since the points are in series with the primary winding of the ignition coil, current will pass through that circuit when the points close. When the points open, the magnetic field in the coil collapses and a high-tension voltage is induced in the secondary windings of the coil by the movement of the magnetic field through the secondary windings. The design is to provide one lobe on the breaker cam for each cylinder of the engine. So a sixcylinder engine will have a six-lobe cam in the distributor and an eight-cylinder engine will have an eight-lobe cam so every revolution of the breaker cam will produce one spark for each cylinder of the engine. On a four-cycle engine, each cylinder fires every other revolution so the distributor shaft must revolve at one half-crankshaft speed. After the high-tension surge is produced in ignition coil by the opening of the breaker points, the current passes from the coil 
to the center terminal of the distributor cap. From there, it passes down to the rotor mounted on the distributor shaft and revolves it. The current passes along the rotor, and jumps the tiny gap to the cap electrode under which the rotor is positioned at that instant. This cap electrode is connected by high tension wiring to the spark plug. As the rotor continues to rotate, it distributes current to each of the cap terminals in turn.

The coil is a compact, electrical transformer that boosts the battery's 12 volts to as high as 20000 volts. The incoming 12 volts of electricity passes through a primary winding of about 200 turns of copper wire that raises the power to about 250 volts. Inside the distributor, this low-voltage circuit is continuously broken by the opening and closing of the points, each interruption causing a breakdown in the coil's electromagnetic field. Each time the field collapses, a surge of electricity passes to a secondary winding made up of more than a mile of hair like wire twisted into 25000 turns. At this point, the current is boosted to the high voltage needed for ignition and is then relayed to rotor.

A spark plug is inserted into the combustion chamber of an engine, containing a side electrode and insulated center electrode spaced to provide a gap for firing and electrical spark to ignite air fuel mixtures. The high voltage burst from the coil via the distributor is received at the spark plug's terminal and conducted down a center electrode protected by a porcelain insulator. At the bottom of the plug, which projects into the cylinder, the voltage must be powerful enough to jump a gap between the center and side electrodes through a thick atmosphere of fuel mixture. When the spark bridges the gap, it ignites the fuel in the cylinder.

The spark plug wire carries 20000 or more volts from the distributor cap to the spark plug. Spark plug wires are made of various layers of materials. The fiber core, inside the spark plug wire carries the high voltage.

As the rotor rotates inside the cap, it receives the high voltage from the ignition coil, then passes it to the nearest connection, which is a metal projection in the cap, which is connected to a spark plug.

A distributor rotor is designed to rotate and distribute the high-tension current of the towers of the distributor cap. The firing end of the rotor, from which the high-tension spark jumps to each of the cap terminal, should not be worn. Any wear will result in resistance to the hightension spark. The rotor with a worn firing end should be replaced. 
Rotors are mounted on the upper end of the distributor shaft. In this connection, the rotor must have snug fit on the end of the shaft. The rotor is driven directly by the camshaft. Advancing the spark timing allows the engine to run efficiently.

The initial source of a vehicle for electricity is a battery. A battery starts the engine. Once the engine is in running condition, an alternator takes over to supply the car's electrical needs and to restore energy to the battery. A 12-volt storage battery consists of layers of positively and negatively charged lead plates that, together with their insulated separators, make up each of six 2-volt cells. The cells are filled with an electricity conducting liquid that is usually twothird distilled water and one-third sulfuric acid. Spaces between the immersed plates provide the most exposure to the electrolyte. The interaction of the plates and the electrolyte produces chemical energy that becomes electricity when a circuit is formed between the negative and positive battery terminals.

Primary current produces a magnetic field around the coil windings. This does not occur instantly, because it takes time for the current and the magnetic field to reach maximum value. The resistance of the coil winding or the length of time the distributor contacts are closed determines the time element. The current does not reach the maximum because the contacts remain closed for such a short time and more so at higher engine speeds. When the breaker points begin to open, the primary current would continue to flow. This condition in a winding is increased by means of the iron core. Without an ignition condenser, the induced voltage causing this flow of current would create an arc across the contact points and the magnetic energy would be consumed in this arc. As a result, the contact points would be burned and ignition would not occur. The condenser prevents the arc by making a place for the current to flow. It is the rapid cutting out of magnetic field that induces high voltage in the secondary windings. If the condenser goes bad, the high voltage needed to jump the gap at the spark plugs would not be possible. This could cause a no-start condition or a driving problem.

\subsection{Fuel injection and exhaust system}

The carburetor is a compromise. No matter how much progress has been made in this area like air bleeds, correction jets, acceleration pumps, emulsion tubes and choke mechanism etc. but carburetor is never perfect to perform according to expectations. The limitation of carburetor 
design is helping to push the industry toward fuel injection. Direct fuel injection means that the fuel is sprayed directly into the combustion chamber. The fuel-injection nozzle is located in the combustion chamber. Fuel is injected through the injectors. Multi-point systems use one injector per cylinder, and usually the injector is located at the mouth of the intake port.

The fuel injector is an electromechanical device that sprays and atomizes the fuel. The fuel injector is nothing more than a solenoid through which gasoline is metered. When electric current is applied to the injector coil, a magnetic field is created, which causes the armature to move upward. This action pulls a spring-loaded ball off its seat. Then, fuel under pressure can flow out of the injector nozzle. The shape of the pintle valve (ball) causes the fuel to be sprayed in a cone-shaped pattern. When the injector is de-energized, the spring pushes the ball onto its seat, stopping the flow of fuel.

Mechanical fuel injection is the oldest of the fuel injection systems. It uses a throttle linkage and a governor. It is now mainly on diesel engines. Hydraulic fuel injection is used by some of the imports. Hydraulic pressure is applied to a fuel distributor as a switching device to route fuel to a specific injector. The fuel from the tank is carried under pressure to the fuel injector by an electric fuel pump, which is located in or near the fuel tank. All excess fuel is returned to the fuel tank.

In an electronic fuel injection system, the injectors are opened not due the pressure of the fuel in the delivery lines but by solenoids, which are operated by an electronic control unit. Since the fuel has no resistance to overcome, other than insignificant friction losses, the pump pressure is set at very low values, considering the limits of obtaining full atomization with the type of injectors used. The amount of fuel to be injected is determined by the control unit on the basis of information fed into it about the engine's operating condition.

The emission of the vehicles is the largest source of pollution on earth. In 1998 the road transport created the following emissions in Sweden only [1]:

口 $37 \%$ of the total nitrogen oxide $\left(\mathrm{NO}_{\mathrm{X}}\right)$ emissions

․ $38 \%$ of the non methane volatile organic compound (NMVOC) emissions

ㅁ $27 \%$ of the carbon dioxide $\left(\mathrm{CO}_{2}\right)$ emissions

口 Also produced particulate matter (PM), which is not reported in the study.

Although emissions of nitrogen oxide, non-methane volatile organic compound, and particulate matter have been reduced but $\mathrm{CO}_{2}$ is still on the rise. 
Combinations of $\mathrm{Pt}$ and $\mathrm{Rh}$ play important role in three-way catalyst to reduce nitrogen oxides and to oxidize $\mathrm{CO}$ and HC. [5]

With the help of three-way catalyst the air to fuel ratio is optimized. In a three-way catalyst arrangement, the lambda sensor senses the amount of $\mathrm{CO}$ and $\mathrm{HC}$ in exhaust and a reaction takes place to convert $\mathrm{CO}$ and $\mathrm{HC}$ before the exhaust approaches to a catalyst placed in the exhaust manifold.

Development of more effective catalyst for $\mathrm{NO}_{\mathrm{x}}$ is still needed.

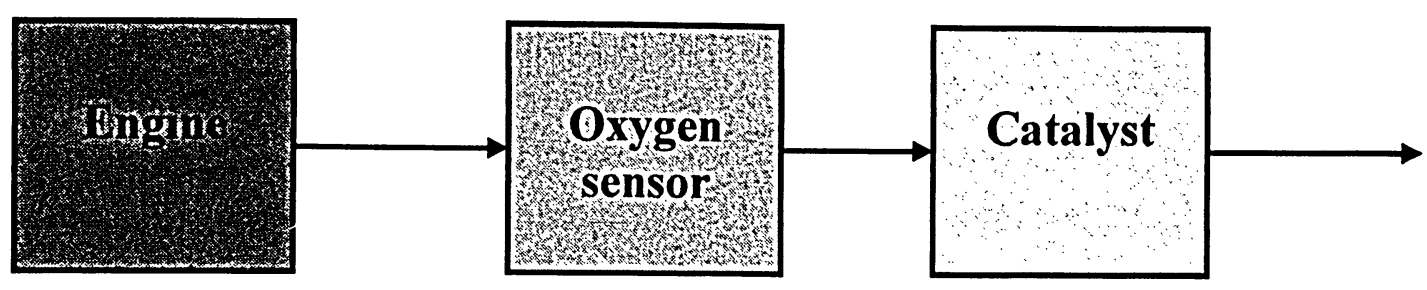

Fig 7: An illustration of catalyst with lumda sensor

\subsection{Manifolds}

The fuel mixture from the carburetor to the intake valves of the engine is conducted through a system of passages which is called an intake manifold. The efficiency of an engine depends on manifold design. The fuel charge, which is taken into each cylinder, must be of the same strength and quality for smooth operation of the engine. Distribution of fuel should be as even as possible depending upon the design of the intake manifold. Dry fuel vapor is an ideal form of fuel charge, but fuel prevents this unless the mixture is subjected to high temperature. The power of the engine is reduced if the fuel charge is heated too high because the heat expands the fuel charge. It is better to have some of the fuel deposited on the walls of the cylinders and manifold vents. Manifolds in modern engines are designed so that the amount of fuel condensing on the intake manifold walls is reduced to a minimum.

The exhaust manifold, which is constructed of cast iron, is a pipe that conducts the exhaust gases from the combustion chambers to the exhaust pipe. It has smooth curves in it for 
improving the flow of exhaust. The exhaust manifold is bolted to the cylinder head, and has entrances for the air that is injected into it. It is usually located under the intake manifold. A header is a different type of manifold. It is made of separate equal-length tubes.

There is another system of manifolds called the ram induction manifold system. It consists of twin air cleaner, twin four-barrel carburetors and two manifolds containing eight long tubes of equal length. This system is used to increase power output in the middle speed range.

\subsection{Fuel pump}

There are three functions of fuel pump:
a To deliver enough fuel according to the requirements of an engine
․ To maintain enough pressure in the line between the carburetor and the pump to keep the fuel from boiling.
․ To prevent vapor lock.

Excessive pressure can hold the carburetor float needle off its seat, causing high gasoline level in the float chamber. This results in high gasoline consumption. The pump generally delivers a minimum of ten gallons of gasoline per hour at top engine speeds, under an operating pressure of from about $2 \frac{1}{2}$ to 7 pounds. Highest pressure occurs at idling speed and the lowest at top speed. Although all fuel pumps work to produce the same effect, there are various types, which may operate somewhat differently.

A mechanical fuel pump has a vacuum booster section. The fuel pump arm operates the vacuum section. During the suction stroke, the rotation of the eccentric on the camshaft puts the pump-operating arm into motion, which pulls the lever and diaphragm down against the pressure of the diaphragm spring and produces suction or vacuum in the pump chamber. The suction holds the outlet valve closed and pulls the inlet valve open thus causing fuel to flow through the filter screen and down through the inlet valve of the pump chamber.

During the return stroke, the diaphragm is forced up by the diaphragm spring. In this process the inlet valve closes and the outlet valve opens to allow fuel to flow through the outlet to the carburetor. The operating lever is hinged to the pump arm so that it can move down but cannot be raised by the pump arm. The pump arm spring forces the arm to follow the cam without moving the lever. The lever can only be moved upward by the diaphragm spring. This process 
causes fuel to be delivered to the carburetor only when the fuel pressure in the outlet is less than the pressure maintained by the diaphragm spring. This happens when the passage of fuel from the pump into the carburetor float chamber is open and the float needle is not seated.

Electric fuel pumps are used for many years on trucks, buses and heavy equipment and they are used as replacements for mechanically operated fuel pumps on automobiles. A relay for the electric fuel pump is used to complete the circuit to the fuel pump. This cuts off current to the fuel pump in the events of an accident.

\subsection{Fuel tank}

A pump feeds fuel to engine. The fuel tank is usually at the rear of the chassis under the trunk compartment. Some vehicles have a rear engine with the tank in the forward compartment. The fuel tank stores the excess fuel until it is needed for operation of a vehicle. The fuel tank has an inlet pipe and an outlet pipe. The outlet pipe has a fitting for fuel line connection and can be located in the top or in the side of the tank. The lower end is about one-half inch above the bottom of the tank so that collected sediment is flushed out. The bottom of the tank contains a drain plug so that tank may be drained and cleaned.

In early days the gas tank were placed higher than the engine. The idea was that the gas could flow down to the engine. There was a problem with this arrangement. When the car would go uphill then the engine would not get gas as the gas flowed away from engine.

\subsection{Fuel filter}

There are many small jets and passages in the carburetor and openings in the fuel injector. So it is necessary that clean fuel be supplied to the engine. For this purpose the fuel filters are installed in the fuel lines. Fuel filters can be located at any point between the fuel tank and the carburetor. One may be in the tank, in the fuel pump or in the carburetor. The most common placement is between the fuel tank and a mechanical fuel pump. In this case, the fuel enters a glass bowl and passes through the filter screen and out through the outlet. Any water or solid material that is trapped by the filter falls to the bottom of the glass bowl where it can be easily 
seen and removed. Dirt particles usually come from scales of rust in the tank of cars. Water comes from condensed moisture in the fuel tanks.

\subsection{Fuel gauges}

Vehicles are equipped with fuel gauges. They are operated along with the vehicle's electrical system. There are two types:

\section{․ The thermostatic type \\ a The balancing coil type}

The thermostatic type is made of a standing unit, located in the fuel tank, and the gauge itself, which is located on the instrument panel. The fuel gauges used in some cars and trucks are of the electrically operated balanced coil type. These have a dash unit and a tank unit. The dash unit has two coils, spaced about 90 degrees apart, with an armature and integral pointer at the intersections of the coil axis. The dial has a scale in fractions between 'Empty' and 'Full'. The tank unit has a housing, which encloses a rheostat, and a sliding brush which contacts the rheostat. The float arm actuates the brush. The movement of the float arm is controlled by the height of the fuel in the supply tank. The height of the fuel changes the value of the dash unit coil so that the pointer indicates the amount of fuel available. A calibrated friction brake is included in the tank unit to prevent the wave motions of the fuel from fluctuating the pointer on the dash units. Current form the battery passes through a limiting coil to a common connection between the two coils, which is the lower terminal on the dash unit. The current then adopts two paths. One through the operating coils of the dash unit and the other over the wire to the tank unit. When the tank is lower or empty, the sliding brush cuts out all resistance in the tanks unit. Most of the current passes through the tank unit circuit because of the low resistance and only a small portion through the operating coil to the dash unit. As a result, this coil is not magnetized enough to move the dash unit pointer, which is then held at the 'Empty' position by the limiting coil.

If the tank is partly full or full, the float rises on the surface of the fuel and moves the sliding brush over the rheostat, putting resistance in the tank circuit. More current passes through the operating coil to give a magnetic pull on the pointer, which overcomes some of the pull of the limiting coil. When the tank is full, the tank unit circuit contains the maximum resistance to the 
pointer to give a 'Full' reading. As the tank empties, the operating coil loses some of its magnetic pull and the limiting coil still has about the same pull so that the pointer is pulled toward the lower reading. Variations in battery voltage do cause an error in the gauge reading because its operation only depends on the difference in magnetic effect between the two coils. Fuel lines that connect all the units of the fuel system are made of rolled steel or of drawn copper. Steel tubing, when used for fuel lines, is generally rust proofed by being copper or zinc plated.

\subsection{Combustion chamber}

This is the place where air-fuel mixture is burned. The location of the combustion chamber is the area between the top of the piston at a top dead center and the cylinder head. The top dead center is the position of piston when it has reached the top of the cylinder, and the centerline of the connecting rod is parallel to the cylinder walls.

There are two types of combustion chamber:

口 Hemispherical combustion chamber

․ Wedge shape combustion chamber

The hemispherical type is called hemispherical because it resembles with the hemisphere. It is compact and allows high compression with a minimum of detonation. The valves are placed on two planes, enabling the use of larger valves. This improves breathing in the combustion chamber. This type of chamber loses a little less heat than other types. The hemispherical combustion chamber is commonly used because it is efficient.

The wedge type combustion chamber resembles a wedge in shape. It is part of the cylinder head. It is also very efficient, and more easily and cheaply produced than the hemispherical type.

\subsection{Supercharger}

A supercharger is basically a compressor. A supercharged engine has a higher overall compression than a non-supercharged engine having the same combustion chamber volume 
and piston displacement and it burns more fuel. The increase in power is not proportional to the increase in fuel consumption. There are two general models of supercharger:

․ Rooter type

- Centrifugal type

The rooter type has two rotors while the centrifugal type uses an impeller rotating at high speed inside a housing. Superchargers can be placed between the throttle body of carburetor or fuel injection system and the manifold or at the air inlet before the throttle body. Racing cars usually have it located between the throttle body and the manifold. This design has the advantage that the fuel can be supplied through the throttle body without modification to any part of the system. If the supercharger is placed in front of the throttle body, fuel must be supplied under sufficient pressure to overcome the added air pressure created by the supercharger. The advantage of a supercharger over a turbocharger is that there is no lag time of boost. As soon as accelerator pedal is depressed, the boost is increased.

\subsection{Turbocharger}

A turbocharger can boost engine power up to $40 \%$. The air-fuel mixture is forced to the cylinders and more power is obtained. A turbocharger is a supercharger that operates on exhaust gas from the engine. Both the chargers are for the same purpose but exhaust gases drive the turbocharger, and belts and gears drive the supercharger. The turbocharger has a turbine and a compressor, and requires less power to be driven than a supercharger. The pressure of the hot exhaust gases cause the turbine to spin. Since the turbine is mounted on the same shaft as the compressor, the compressor is forced to spin at the same time, drawing $50 \%$ more air into the cylinders than is drawn in without the turbocharger. This creates more power when the air-fuel mixture explodes. A lower compression piston is used to lower the engine's compression ratio. Otherwise an excessive amount of pressure would wear on the piston, connecting rods, and crankshaft, and destroy the engine. These parts are strengthened on a turbo engine. 


\subsection{Breathers}

The breather is a positive crankcase ventilation system directing atmospheric pressure to the crankcase. The atmospheric pressure pushes the blowby gases to a low-pressure area. The air that is directed into the crankcase must first be filtered. Otherwise the dust and sand particles destroy the engine parts. When there is too much blowby, it is routed back through the crankcase breather element. It then enters the carburetor with the incoming fresh air to be burned in the cylinders. Breather also helps to keep the regular air filter clean for a longer period of time because blowby contains oil from the crankcase.

\subsection{Vacuum pump}

Many Fuel pumps have two sections:

口 A vacuum booster section.

口 Fuel section

The vacuum booster section operates the windshield wipers at an almost constant speed. The fuel section functions in the same way as ordinary fuel pumps. The rotation of the camshaft eccentric in the vacuum pump also operates the vacuum booster section by actuating the pump arm which pushes a link and the bellows diaphragm assembly upward, expelling air in the upper chamber through its exhaust valve out into the intake manifold. On the return stroke of the pump arm, the diaphragm spring moves the diaphragm down, producing suction in the chamber. The suction opens the intake valve of the vacuum section and draws air through the inlet pipe from the windshield wipers.

When the wipers are not operating, the intake manifold suction or vacuum holds the diaphragm up against the diaphragm spring pressure so that the diaphragm does not function with every stroke of the pump arm. When the vacuum is greater than the suction produced by the pump, the air flows from the windshield wiper through the inlet valve and vacuum chamber of the pump and out the exhaust valve outlet to the manifold, leaving the vacuum section inoperative. With high suction in the intake manifold, the operation of the wiper remains the same as if the pump were not installed. When the suction is low, as when the engine is accelerated or 
operating at high speed, the suction of the pump is greater than that in the manifold and the vacuum section operates the wipers at a constant speed. Some pumps have the vacuum section located in the bottom of the pump instead of in the top, but the operation is the same.

\subsection{Air pump}

The function of the air pump is to send or pump compressed air into the exhaust manifold and in some cases to the catalytic converter. The oxygen in the pressurized air helps to burn quite a bit of any unburned hydrocarbons (fuel) and therefore converts the poisonous carbon monoxide into carbon dioxide. A belt from the engine drives the air pump. It has little vanes that draw the air into the compression chamber. Then the air is compressed and sent off to the exhaust manifold where it speeds up the emissions burning process. Stainless steel nozzles are used to shoot the air into the exhaust manifold, because they do not burn. Some engines use a pulse air injection system. This system uses pulses of exhaust gas to operate an air pump that delivers air into the exhaust system.

\subsection{Air cleaner}

The function of air cleaner is to separate dust and other particles in the incoming air before it enters the carburetor. Thousands of cubic feet of air are drawn from the car hood and passed through the engine cylinders. Therefore it is very important to clean the air to be used in the engine cylinders.

Dusts particles are drawn through the radiator and if they are not filtered they go into the engine. Dust and other foreign materials in the engine cause wear and operating problems.

\subsection{Vibration damper}

A device that is connected to the crankshaft to lessen the torsional vibration is known as vibration damper or harmonic balancer. Power is transmitted through the crankshaft following the cylinders' fire. The front of the crankshaft takes the brunt of this power, so it often moves 
before the rear of the crankshaft. This results in a twisting motion. When the power is removed from the front, the halfway twisted shaft unwinds and snaps back in the opposite direction. Although this unwinding process is quite small, it causes torsional vibration. A harmonic balancer is attached to the front part of the crankshaft to prevent this vibration.

The balancer is made of two pieces connected by rubber plugs, spring-loaded friction discs or both. When the power from the cylinder hits the front of the crankshaft, it rises to twist the heavy part of the damper, but ends up twisting the rubber or discs connecting the two parts of the damper. The front of the crank cannot speed up as much with the damper attached. The force is used to twist the rubber and speed up the damper wheel. This keeps the crankshaft operation calm.

\subsection{Timing belts}

The automobile engine uses a metal timing chain, or a flexible toothed timing belt to rotate the camshaft. The crankshaft drives the timing chain/ belt. The timing chain, or timing belt is used to 'time' the opening and closing of the valves. The camshaft rotates once for every two rotations of the crankshaft.

\subsection{Metering rod}

A metering rod varies the size of the carburetor jet opening. Fuel from the float bowl is metered through the jet and the metering rod within it. The fuel is forced from the jet to the nozzle extending into the venturi. As the throttle valve opens, its linkage raises the metering rod from the jet. The rod has several steps, or tapers, on the lower end. As it is raised in the jet, it makes the opening of the jet greater in size. This allows more fuel to flow through the jet to the discharge nozzle. The metering must keep pace with the slightest change in the throttle valve position so that the correct air fuel mixture is obtained in spite of engine speed. 


\subsection{Radiator}

This is a device to dissipate the heat that the coolant has absorbed from the engine. It is constructed to hold a large amount of water in tubes or passages, which provide a large area in contact with the atmosphere. It usually consists of a radiator core, with its water-carrying tubes and large cooling area, which are connected to a receiving tank at the top and to a dispensing tank at the bottom. Slide flow radiators have their 'end caps' on the sides, which allows a lower hood line.

During the operation, the water is pumped from the engine to the top tank, where it spreads over the tops of the tubes. As the water passes down through the tubes, it loses its heat to the airstreams, which passes around the outside of the tubes. To help spread the heated water over the top of all the tubes, a baffle plate is often placed in the upper tank, directly under the inlet hose from the engine.

\subsection{Cooling fans}

The air is passed through the radiator to cool the coolant. When the vehicle runs at a moderate to high speed, the air rushes through the grille of the vehicle and passes through the radiator core. If the vehicle does not go fast enough to push the air through the radiator, then the fan pulls the air towards the radiator.

The cooling is improved when the vehicle moves at low speed or if engine is idling. It is usually mounted on the water pump shaft, and is turned by the same belt that drives the water pump and the alternator, although it can be mounted as an independent unit. Most independently mounted fans are electric.

The following are pros and cons of IC engines:

\section{Pros}

a Gasoline and diesel are available in abundance for use in ICE vehicles. 
ICE can be operated on alternate fuels like biodiesel, compressed natural gas, ethanol, methanol, and propane.

口 $\quad 40 \%$ energy can be saved if the road load (i.e. air resistance, rolling resistance and energy for acceleration) is reduced and more efficient power trains are used.

- Efficiency of an ICE can be improved if valve timing, shut-off during idling, higher compression ratio is taken into account.

- ICE is most likely the strong candidate for today and future hybrid vehicles

口 Energy and environmental cost can be improved by $50 \%$ by improving ICE

- Air to fuel ratio is controlled through the use of Three Way Catalyst. In this catalyst the oxidation of $\mathrm{HC}$ and $\mathrm{CO}$ takes place through $\mathrm{Pt}$ and reduction of NOx is done through Rh. In this way the emissions are controlled but not finished at all in a gasoline engine.

- Liquid particulates (SOF), $\mathrm{CO}$, and $\mathrm{HC}$ emissions are reduced from diesel engine through monolithic catalysts but NOx is again a challenge for future researchers.

\section{Cons}

- ICE is has very complex components.

口 ICE has too many parts.

口 It needs a lot of vendors

口 Many resources are required.

a Emission like CO, NOx, HC and PM are polluting environment.

口 ICE gives vibrations.

a Use of advance systems of catalyst has only reduced the emissions but has not fully finished them.

․ Lean burn gasoline engine needs reduction of NOx.

口 In diesel engines, emission of NOx has to be reduced. 


\section{Chapter 4: Fuel Cell}

In 1839, Sir William Grove, a physicist in England, produced electricity through an electrochemical reaction of hydrogen and oxygen. Since then no significant achievement was made until the air pollution and oil crisis compelled the researchers to go for fuel technology [19]. High efficiency, excellent performance, low emissions and wide size range make a fuel cell favorite for future use [6]. Fuel cell systems can be followed to operate cell phone to automobiles to power plants.

Operation of a fuel cell is like a battery. A fuel cell does not run down or require recharging opposing the battery in this aspect. When fuel is supplied to the fuel cell, it produces energy in the form of electricity.

Like a battery the fuel consists of two electrodes and an electrolyte. Oxygen is passed over one electrode and hydrogen is passed over the other electrode. In this process electricity and water are produced.

The electrode, which is supplied with hydrogen, is called anode of the fuel cell and the electrode, which is supplied with the oxygen, is called cathode.

Due to the presence of a catalyst, the hydrogen atoms split into a proton and an electron, which take different paths to the cathode. The protons pass through the electrolyte. The electrons pass through the external circuit and thus producing current, which can be utilized, and which is the main product of the fuel cell. Oxygen and hydrogen combine to form water.

A fuel reformer is a device, which produces hydrogen to be used in fuel cell. The reformer is used if the fuel from any hydrocarbon is used. In a fuel cell there is no combustion like an internal combustion engine so the emissions during the production of hydrogen using hydrocarbon fuel in a reformer are much smaller as compared to internal combustion engine. The fuel cell has the following advantages:

․ High energy conversion efficiency

口 Modular design

口 Flexibility of size

․ Low environmental impact

․ Rejection of heat at high temperature in some fuel cells

口 Quick response to load changes 
Fuel cells have some disadvantages:

․ Sensitivity to certain contaminants

口 Current capital costs are high

口 Lack of the field data on endurance

The main advantage of fuel cells is the high conversion efficiency, which may range from $\mathbf{4 0}$ to $60 \%$ based on lower heating value of the fuel. The fuel conversion efficiency is higher than that of most energy conversion systems. The efficiency advantage becomes more significant at the smaller scales since the efficiency of fuel cells is nearly constant with size.

The heat rejected from some of the fuel cell types such as the Molten Carbonate and the Solid Oxide fuel cells is at high temperature and thus, is available for cogeneration applications.

Fuel cell plants can be constructed in a wide range of electrical output, from less than a $\mathrm{kW}$ to sizes in excess of a MW. Fuel cells produce no gaseous, solid or noise emissions. Fuel cells are sensitive to certain fuel contaminants such as sulfur and chlorides. The fuel entering the fuel cell has to be gaseous and in some cases has to be hydrogen, which leads to the requirement of a fuel pre-processor such as a reformer. In some fuel cell designs the reformer has been incorporated within the fuel cell itself. The fuel cell can be classified as:

a Fuel cells externally reformed

口 Fuel cells internally reformed

口 By the type of electrolyte used

․ By the temperature of operation

Usually the type of electrolyte used classifies the fuel cells.

\subsection{Working of a fuel cell}

A fuel cell is similar to battery in a sense that both fuel cell and battery allow electro chemical reaction and fuel is converted to electricity. In both cases there is no combustion.

The main difference is that a battery has a finite supply of reactants, while the fuel cell can run indefinitely as long as their reactant $\mathrm{s}$ are replenished. When a fuel such as hydrogen is provide through an electrode, called anode, in the presence of a catalyst, electrons are separated from the fuel and go through the external circuit. The remaining positive ions travel through the 
electrolyte to other electrode, called cathode, where they combine with oxygen ions. The products for the reaction are:

a Heat

․ Water in the from of steam

ㅁectricity

All types of fuel cells have same general design. Usually they differ due to the electrolyte used in them. Different type of electrolyte are present these days which can be used in fuel cells. Depending upon the type of electrolyte there are six main types of fuel cells:

口 Alkaline fuel cells (AFC)

口 Solid polymer fuel cells, also called proton exchange membrane fuel cells (PEMFC)

ㅁ Phosphoric acid fuel cells (PAFC)

․ Molten carbonate fuel cells (MCFC)

口 Solid oxide fuel cells (SOFC)

口 Direct Methanol Fuel Cell (DMFC)

Alkaline and solid polymer fuel cells operate at lower temperatures and are mainly designed for transportation applications. The other three operate at higher temperatures and are being developed for use in cogeneration and large central plants. At present Proton Exchange Membrane Fuel Cells are considered favourite for vehicular power. Direct Methanol Fuel Cells are also considered for vehicular power but they cannot compete with the Proton Exchange Membrane Fuell Cells.

Fuel cell basics are shown in the following figure 4. Electricity is generated through the electrochemical reaction of the fuel cell. Oxygen and hydrogen form water and heat is released. 


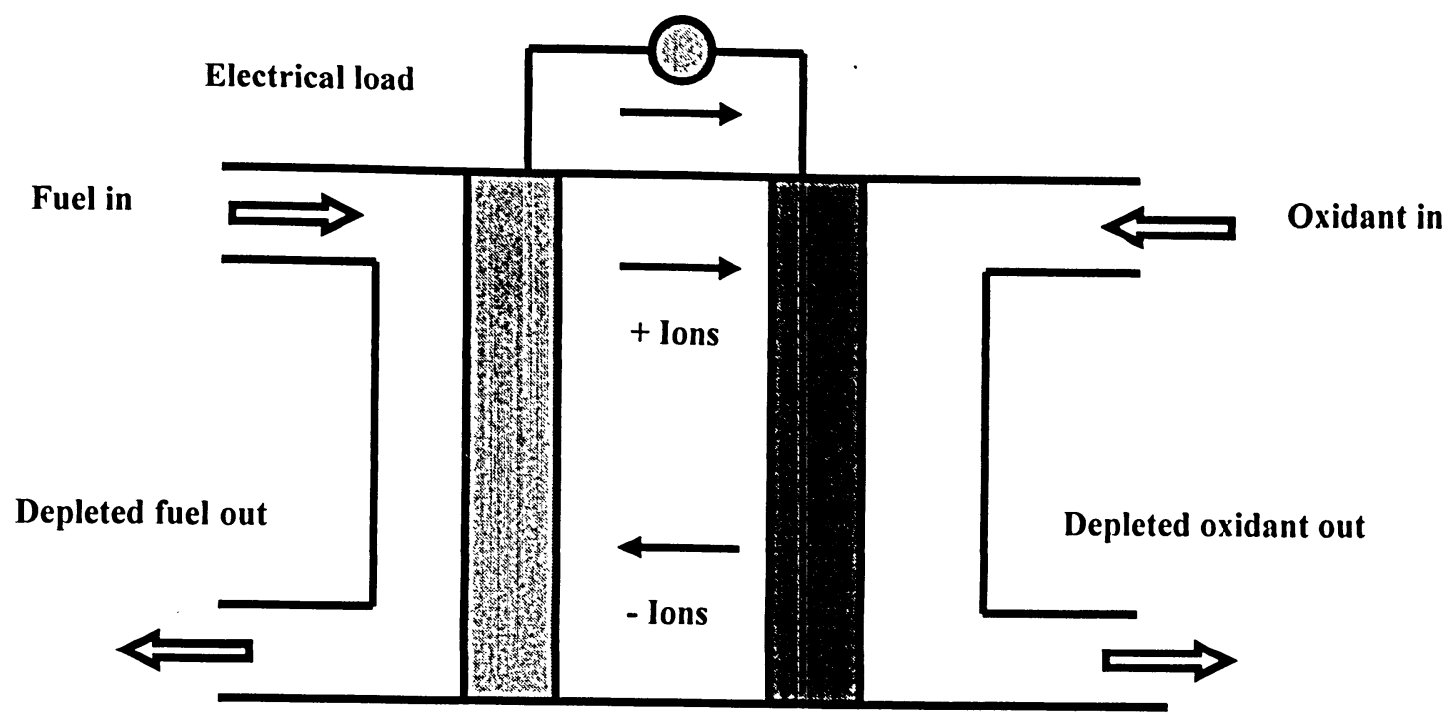

Figure 8: Fuel cell basics [6]

\subsection{Fuel cell systems}

The following sub systems of a fuel cell are shown in figure 5:

․ The fuel cell stack

ㅁ The fuel cell processor

․ Air management

․ Water management

․ Thermal management

․ Power conditioning

A fuel processor converts the source fuel to a hydrogen rich fuel stream. The fuel processor is relatively complex and usually includes a desulfurizer, a stream reformer, shift converters, and a gas clean-up system to remove carbon monoxide from the anode gas stream.

A single cell produces a potential according to its capacity. Stacking individual cells in series realize a practical voltage. Separator plates are placed between the cells. These plates are made of electrically conducting materials such as graphite or corrosion resistant metals. These plates are shaped in such a way that the reactants have access to the electrodes. Similar plates are used for cooling the stack, although the cooling function may be imbedded in the separator 
plates. The stack also has a section to humidify the reactant gases. The stack is completed with current collector plates, end plates and tie rods.

The number of cells in one stock ranges form 10 to about 100. The individual cell surface ranges from 100 to $300 \mathrm{~cm}^{2}$. One stack can produce power between less than $1 \mathrm{~kW}$ up to some $100 \mathrm{~kW}$. For stacks operating on air and $\mathrm{H}_{2}$, the highest power density achieved so far is in the order of $1 \mathrm{~kW} / \mathrm{l}$ or $1 \mathrm{KW} / \mathrm{kg}$.

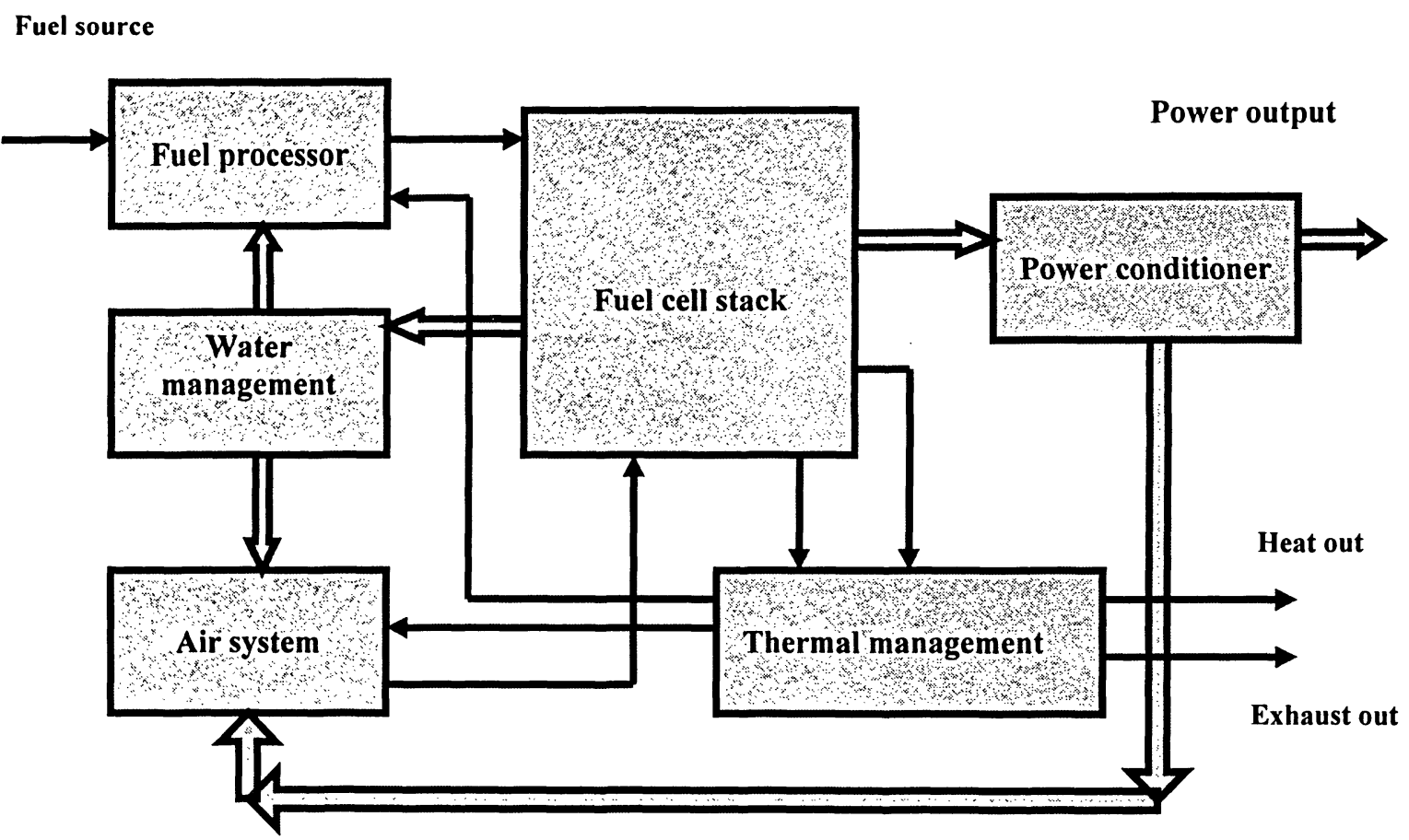

Figure 9: Fuel cell system schematic [6]

There are two main choices for the air supply system:

- A blower

- A Compressor

The blower supplies near ambient pressure air to the fuel cell stack but can vary the mass flow rate supplied $t$ the stack in order to achieve variable air stoichiometric ratios. A compressor can provide either relatively fixed pressure air to the fuel cell stack at varying mass flow rates, or 
supply both variable air pressure and variable air mass flow. These two types of air supply systems provide highly diluted oxygen (humidified) to the fuel cell cathode. The strong dilution of the oxygen feed stream dramatically affects the oxygen partial pressure at the cathode catalyst layer, and, in turn, this leads to the need for high over potentials on the cathode.

Flooding of the cathode and anode backing layers due to excess water and drying out of the membranes can seriously impact the operation of PEM fuel cell stacks. Flooding occurs when the combination of the water carried into the anode and cathode by the humidified gases plus the water produced in the reaction between hydrogen and oxygen is not removed efficiently from he respective backing layers. Flooding impairs the ability of the reactant gases to diffuse through the backing layers to the catalytic reaction sites. This effect significantly increases the cathode over-potential required to generate high cell current, and ultimately limits the peak power output of the stack. Insufficient supply of water can dry out the anode side of the PEM fuel cell membrane, causing a significant rise in stack resistance and reduced membrane durability. To ensure that the stack remains properly humidified and does not flood, a water management system humidifies the incoming feed gases and removes the excess water from the cathode and anode exhaust streams. This water can be re-used for gas humidification. A thermal management system maintains the fuel cell stack operating temperature within a narrow range under widely varying power demands. The thermal system is also necessary for quick warm-up and safe cool down of the stack during off-and-on operating conditions of the fuel cell. 


\subsection{Types of fuel cells}

Types of fuel cells are described below:

\subsubsection{Phosphoric Acid Fuel Cell (PAFC)}

The PAFC consists of porous carbon electrodes surrounding a porous matrix that retains the liquid phosphoric acid electrolyte. The PAFC operates with efficiencies comparable with PEMFC but it has lower power density. [6]

Phosphoric Acid fuel cell generates electricity at more than $40 \%$ efficiency. And nearly $85 \%$ of the steam produced by this type of fuel cell is used for cogeneration. This type of fuel cell is in wide use today. Many fuel cells have been installed in hospitals, nursing homes, hotels, office buildings, schools, utility power plants, an airport terminal, landfills and waste water treatment plants.

The temperatures at which it operates are in the range of 300 to 400 degrees F. At lower temperatures, the phosphoric acid is a poor ionic conductor, and carbon monoxide poisoning of the platinum electro-catalyst in the anode becomes severe.

The electrolyte is liquid phosphoric acid soaked in a matrix. One of the main advantages to this type of fuel cell is that it can use impure hydrogen as fuel. Phosphoric Acid fuel cells can tolerate a carbon monoxide concentration of about 1.5 percent, which broadens the choice of fuels they can use. If gasoline is used, the sulfur must be removed.

Disadvantages of Phosphoric Acid fuel cells are:

口 They use expensive platinum as catalyst

口 They generate low current and power

․ They have large size and weight

Reaction at anode is given as:

$$
\mathrm{H}_{2}(\mathrm{~g}) \longrightarrow 2 \mathrm{H}+(\mathrm{aq})+2 \mathrm{e}-
$$

Reaction at cathode is given as:

$$
1 / 2 \mathrm{O}_{2}(\mathrm{~g})+2 \mathrm{H}+(\mathrm{aq})+2 \mathrm{e}-\longrightarrow \mathrm{H}_{2} \mathrm{O}(\mathrm{l})
$$


Cell reaction is: $\mathrm{H}_{2}(\mathrm{~g})+1 / 2 \mathrm{O}_{2}(\mathrm{~g})+\mathrm{CO}_{2}$ $\mathrm{H}_{2} \mathrm{O}(\mathrm{l})+\mathrm{CO}_{2}$

\subsubsection{Proton Exchange Membrane Fuel Cell (PEMFC)}

The PEMFC can be used as a replacement for the internal combustion engine. This fuel cell is efficient and provides high power density. A density of $1.35 \mathrm{~kW} /$ litre has been demonstrated so far [6]. They are the most promising fuel cells for light-duty vehicles, for buildings, and potentially for much smaller applications such as replacement for rechargeable batteries. The Proton Exchange Membrane fuel cells operate at relatively low temperatures (about 175 degrees F). They have high power density. They can vary their output quickly to meet shifts in power demands. They are very suitable where quick start up is required, like automobiles. In these cells there is a thin plastic sheet, which is called proton exchange membrane, which allows hydrogen ions to pass through it. There is a coating on both sides of the membrane. The coating is of highly dispersed metal alloy particles. These alloy particles are called catalysts.

The electrolyte used is a solid organic polymer poly-perflourosulfonic acid. The advantage of solid electrolyte is that it reduces corrosion and management problems.

Hydrogen is given to the anode side of the fuel cell where the catalyst helps the hydrogen atoms to release electrons and become hydrogen ions (protons). Due to traveling of electrons, an electric current is obtained that can be utilized before it returns to the cathode side of the fuel cell where oxygen has been fed. At the same time, the protons diffuse through the membrane (electrolyte) to the cathode, where the hydrogen atom is recombined and reacted with oxygen to produce water, thus completing the overall process. This type of fuel cell is sensitive to fuel impurities. Cell output is ranged from 50 to $250 \mathrm{~kW}$.

Reaction at the anode of the cell is given as: [6]

$\mathrm{H}_{2}(\mathrm{~g}) \longrightarrow 2 \mathrm{H}+(\mathrm{aq})+2 \mathrm{e}-$

The reaction at the cathode of the cell is given as:

$1 / 2 \mathrm{O}_{2}(\mathrm{~g})+2 \mathrm{H}+2 \mathrm{e}-\longrightarrow \mathrm{H}_{2} \mathrm{O}(\mathrm{l})$

The cell reaction is: 
$\mathrm{H} 2(\mathrm{~g})+1 / 2 \mathrm{O}_{2}(\mathrm{~g})$

$\mathrm{H}_{2} \mathrm{O}(\mathrm{l})$

The above fuel cell reaction shows that hydrogen and oxygen combine to give water.

\subsubsection{Molten Carbonate Fuel Cell (MCFC)}

In this type of fuel cell a liquid solution of lithium, sodium and /or potassium carbonate, soaked in a matrix for electrolyte is used. Collector plates and cell separator plates are typically fabricated from stainless steel, which can be formed less expensively than the carbon plates in the PEMFC and PAFC cells. Due to high operating temperature sufficient conductivity of electrolyte is achieved. They have high fuel-to-electricity efficiencies. They operate at about 1200 degrees F. [6]

The high temperature eliminates the requirement of catalyst for the fuel cell's electrochemical oxidation and reduction processes.

Hydrogen, carbon monoxide, natural gas, propane, landfill gas, marine diesel, and simulated coal products are used to supply fuel to the fuel cell. They range from $10 \mathrm{~kW}$ to $2 \mathrm{MW}$ using different kind of fuels. High efficiency is achieved due to high operating temperature because at high temperatures different kind of fuels can be used and expensive catalysts can be avoided. The breaking of carbon bonds in large hydrocarbon fuels occurs faster at high temperature.

At high temperature the chances of getting corrosion increase and also the breakdown of cell components takes place.

Reaction at anode is:

$\mathrm{H}_{2}+\mathrm{CO}_{3}{ }^{2-} \longrightarrow \mathrm{H}_{2} \mathrm{O}+\mathrm{CO}_{2}(\mathrm{~g})+2 \mathrm{e}^{-}$

Reaction at cathode is:

$1 / 2 \mathrm{O}_{2}(\mathrm{~g})+\mathrm{CO}_{2}(\mathrm{~g})+2 \mathrm{e}^{-} \longrightarrow \mathrm{CO}_{3}^{2-}$

Cell reaction is:

$\mathrm{H}_{2}+1 / 2 \mathrm{O}_{2}(\mathrm{~g})+\mathrm{CO}_{2}(\mathrm{~g})+\mathrm{CO}_{3}{ }^{2-} \longrightarrow \mathrm{H}_{2} \mathrm{O}(\mathrm{g})+\mathrm{CO}_{2}(\mathrm{~g})+\mathrm{CO}_{3}{ }^{2-}$ 


\subsubsection{Solid Oxide Fuel Cell (SOFC)}

The high operating temperatures of SOFC simplify system configuration by permitting internal reforming and also facilitate the development of cogeneration systems as well as hybrid power systems for production power. Industrial and large-scale electricity generating stations, and high power applications use this type of fuel cells. In this type of fuel cells the electrolyte is not used in form of liquid [6].

Hard ceramic material of solid zirconium oxide and a certain amount of Ytrria is used instead of liquid. This allows an operating temperature of 1800 degrees F. Power generating efficiencies in this type of fuel cell is $60 \%$. Cell out put is upto $100 \mathrm{~kW}$.

Anode reaction is given as [6]:

$\mathrm{H}_{2}(\mathrm{~g})+\mathrm{O}^{2-} \longrightarrow \mathrm{H}_{2} \mathrm{O}(\mathrm{g})+2 \mathrm{e}^{-}$

Cathode reaction is given as:

$1 / 2 \mathrm{O}_{2}(\mathrm{~g})+2 \mathrm{e}^{-} \longrightarrow \mathrm{O}^{2-}$

Cell reaction is:

$\mathrm{H}_{2}(\mathrm{~g})+1 / 2 \mathrm{O}_{2}(\mathrm{~g}) \longrightarrow \mathrm{H}_{2} \mathrm{O}(\mathrm{g})$

\subsubsection{Alkaline Fuel Cell}

AFCs are used for electricity generation and water. They have an efficiency of $70 \%$. They have an operating temperature of 150 to $200{ }^{\circ} \mathrm{F}$. An aqueous solution of alkaline potassium hydroxide soaked in a matrix is used as an electrolyte.

The advantage of using this type of fuel cell is that reaction at cathode is faster in the alkaline electrolyte. The faster reaction gives high performance. Their manufacturing cost is very high. They have a cell output of 300 watts to $5 \mathrm{KW}$.

Anode reaction is given as:

$\mathrm{H}_{2}(\mathrm{~g})+2(\mathrm{OH}) \longrightarrow 2 \mathrm{H}_{2} \mathrm{O}(\mathrm{l})+2 \mathrm{e}-$

Cathode reaction is given as:

$1 / 2 \mathrm{O}_{2}(\mathrm{~g})+\mathrm{H} 2 \mathrm{O}(\mathrm{l})+2 \mathrm{e}-\longrightarrow 2(\mathrm{OH})$ 
The cell reaction is given as:

$\mathrm{H}_{2}(\mathrm{~g})+1 / 2 \mathrm{O}_{2}(\mathrm{~g}) \longrightarrow \mathrm{H}_{2} \mathrm{O}(\mathrm{l})$

\subsubsection{Direct Methanol Fuel Cells (DMFC)}

Simple storage requirements, simple construction and transportation are its prominent features [7]. In this type the fuel used is methanol, which is dissolved in liquid water and supplied to the anode. In this case no fuel processor is needed. This fuel cell can also be used as a replacement of batteries [6]. The electrolyte used in this type of fuel cell is a polymer membrane. In this sense it resembles with the Polymer Exchange Membrane fuel cell. A big advantage of this fuel cell is that it does not need any reformer as its anode catalyst can utilize hydrogen generated from the liquid methanol. In this type of fuel cell the efficiency is $40 \%$ and it operates at a temperature of $120-190{ }^{\circ} \mathrm{F}$. This type of fuel cell is suitable for small to mid sized applications. It can be used to operate cell phones, and laptops etc.

Problems with the fuel cell:

- A problem with this type of fuel cell is fuel crossing over from the anode to the cathode through polymer without producing electricity, which results in low efficiency.

a Reaction rate is slow due to available catalyst that leads to the other cause of low efficiency.

Anode reaction is given as: [6]

$\mathrm{CH}_{3} \mathrm{OH}(\mathrm{aq})+\mathrm{H}_{2} \mathrm{O}(\mathrm{l}) \longrightarrow \mathrm{CO}_{2}(\mathrm{~g})+6 \mathrm{H}^{+}+6 \mathrm{e}^{-}$

Cathode reaction is given as:

$6 \mathrm{H}^{+}+6 \mathrm{e}^{-}+3 / 2 \mathrm{O}_{2}(\mathrm{~g})$ $3 \mathrm{H}_{2} \mathrm{O}(1)$

Cell reaction is given as:

$\mathrm{CH}_{3} \mathrm{OH}(\mathrm{aq})+3 / 2 \mathrm{O}_{2}(\mathrm{~g}) \longrightarrow \mathrm{CO}_{2}(\mathrm{~g})+2 \mathrm{H}_{2} \mathrm{O}(\mathrm{l})$ 


\section{Chapter 5: Fuel Cell - A better choice}

For an ideal vehicular power generating unit the following criterion should be met:

$\begin{array}{ll}\square & \text { Rapid startup } \\ \square & \text { Fast pickup } \\ \square & \text { High power density } \\ \square & \text { Great fuel efficiency } \\ \square & \text { Easy handling } \\ \square & \text { Safe handling } \\ \square & \text { Long lifetime } \\ \square & \text { Low cost } \\ \square & \text { No environmental damage }\end{array}$

The internal combustion engines used in vehicles produce a lot of air pollutants. Due to these pollutants the smog and harmful particulates are produced. Fuel cells do not emit any harmful pollutants. Thus when these are used in vehicles, air pollutant free environment will flourish. It is also true that due to use of reformer, that converts fuels like natural gas, methanol, or gasoline to hydrogen, a small amount of air pollutants can be produced but this amount is far less when compared to the internal combustion engine's emissions.

Burning of fossil fuels such as gasoline or diesel adds greenhouse gases to the atmosphere. Greenhouse gases warm the earth as they trap the heat. Fuel cell vehicles powered by pure hydrogen do not emit any greenhouse gases. Again if the reformer is used, the greenhouse gases will be produced but very small in amount when compared with internal combustion engine.

Due to the use of fuel cell stacks and electric motors, automobile manufacturers have flexibility in designing vehicles. Fuel cell systems are so promising that they are flexible for any design or shape.

Internal combustion engines' automobiles convert less than $20 \%$ of the energy in gasoline into power that moves the vehicle. Vehicles that use electric motors powered by hydrogen fuel cells are much more energy efficient, utilizing 40 to $60 \%$ of the fuel energy. Even if the reformer is used to produce hydrogen from gasoline, even then $40 \%$ of energy of gasoline could be used. 
If fuel cells are used in place of 12 volts batteries in vehicles, they can provide much more power in the automobiles. So the conventional vehicles can have a better powerful electronic system by using fuel cells instead of conventional batteries. Electronic steering and braking are in progress due to advent of fuel cells.

Fuel cells are much quieter as compared to internal combustion engines. In internal combustion engines there are a lot of systems, which contribute to vibrations and noise. Internal combustion engines are very complex and have a lot of parts. Manufacturing of internal combustion engine involves more materials, labor and time. The manufacturing of fuel cell is comparatively less complex and requires less materials and resources.

Fuel cell systems produce electrical energy at very high efficiency. The efficiency is better than that of generators powered by internal combustion engines such as piston engines and gas turbines. If high electrical efficiency is required, fuel cells can be combined with gas turbines. Thus they can surpass the efficiency of combined cycle systems. They would also exhibit zero emission technology.

Fuel cell needs hydrogen to operate and hydrogen can be obtained from biomass or from electrolysis of water using electricity from wind or solar energy. If the efforts to produce electricity from wind or solar energy are successful in future then the fuel cell would be the best choice for coming days. In this way dependence on the oil could be reduced.

Fuel cells have changed the industrial thinking. Every progressive industry is seeking to get benefits from the fuel cell technology.

\subsection{Importance of Proton Exchange Membrane Fuel Cell}

Ballard power systems supplies PEMFC to many automotive manufacturers. Proton Exchange Membrane fuel cells are the best source for vehicular power [8].

They are believed to be future replacement of internal combustion engines. Proton Exchange Membrane fuel cells use a solid polymer membrane as the electrolyte. This polymer is permeable to protons when it is saturated with water, but it does not conduct electrons. The fuel for this type is hydrogen and the charge carrier is the hydrogen ion or proton. At the anode, the hydrogen molecule is split into hydrogen ions and electrons. The hydrogen ions travel across the electrolyte to the cathode while the electrons flow through an external circuit 
and produce electric power. Oxygen, which is obtained from air, is supplied to the cathode and combines with the electrons and the hydrogen ions to produce water.

PEMFCs generate more power for a given volume or weight of fuel cell. This makes them compact and lightweight. The operating temperature is less than $100{ }^{\circ} \mathrm{C}$, which allows rapid start-up. The ability of rapidly changing power output is very useful when these fuel cells are used in vehicles to propel them.

In this type of fuel cell solid material electrolyte is used which is of great advantage. The sealing of the anode and cathode gases is simpler with a solid electrolyte. Due to this reason it is less expensive to manufacture. The solid electrolyte does not have any problem with the way it is oriented and has less problems with corrosion, compared to many other electrolytes, thus leading to a longer cell and stack life.

The bad aspect of the PEMFC is that the operating temperature is low. The useful cogeneration cannot be done at the temperature at which it operates. In this fuel cell the electrolyte is saturated with water so that the fuel cell can operate on optimal conditions. So control of the moisture of the anode and cathode stream is important. The price of this fuel cell has to be decreased 10-20 times to use it on large scale, which is a sort of trade off. [7]. High temperature hydrides are not suitable for PEMFCs. [9]. These fuel cell have also a potential for stationary power generation and a power plant of $200 \mathrm{~kW}$ is in progress. [10].

\subsection{Problems with PEMFC}

The PEMFC is most attractive fuel cell in market today but there are certain factors that prevent it from being the sole choice for all types of vehicles:

口. The cost of this fuel cell is too high for its successful commercialization. It should be reduced at least 10-20 times. Due to its operational conditions, it is suitable for only light duty vehicle. [7].

- As the fuel cell operates at low operating temperature so a costly catalyst (platinum) is needed at electrodes to avoid slow kinetics. [6].

- Fuel processors and system integration need to be competitive. [11]

口 Fuel cell generates 0.6 to 0.8 volts. Its voltage needs to be increased so that fewer cells are required in a stack. 
- Use of PEMFC in power plants reduces the emission like $\mathrm{CO}, \mathrm{NO}_{\mathrm{x}}$ and $\mathrm{HC}$ but it does not eliminate them. [10]

口 Pure hydrogen handling is a big problem, so the processor cannot be removed from such type of propulsion system.

\subsection{The best fuel: Hydrogen}

J. Fernando, in his social cost comparison, has indicated that hydrogen fuel is better than gasoline [20]. Fuel cells operate best on pure hydrogen as it has a high-energy contents per unit mass. The hydrogen can be carried on-board in two ways:

1. Compressed hydrogen gas in storage tanks at high pressure

2. Liquid hydrogen at low pressure and low temperature

Hydrogen can be stored at a pressure of $5000 \mathrm{psi}$ in compressed form [6]. The only hurdle is that the steel tank becomes too heavy so if the tank is made of any other material to accommodate hydrogen at $5000 \mathrm{psi}$ then a range of $400 \mathrm{~km}$ can be achieved, which is acceptable. If pure hydrogen is used then there is no need of any on-board reformer or processor. If pure hydrogen is used an efficient system could be developed.

Metal hydrides are not suitable for medium sized vehicles in near future [9]. If the hydrogen is obtained through the processing of a fuel like gasoline then the goal to achieve zero emission can never be achieved.

\section{Pros}

․ Fuel cells can use pure hydrogen as a fuel which leads to zero emission future

a Fast start-up and high conversion efficiency make PEM fuel cell favorite for vehicular power

a No moving parts like ICE so no noise and vibration

口 They can replace ICE in hybrid vehicles making environment cleaner.

a If reformer is used they can use many fuels like natural gas, gasoline, methanol

․ The fuel cells are used to produce electricity 
․ They are quiet

ㅁ Efficient

口 Clean

ㄴow maintenance cost due to less parts

- Operation keeps going as far as fuel is supplied

ㅁ More fuel efficiency is achieved

\section{Cons}

ㅁ Different fuel cells have different qualities. No one is completely ideal for vehicular power

ㅁ So far gasoline is the only fuel which is easily available for fuel cell which is a cause of pollution

․ Lack of infrastructure to implement pure hydrogen campaign

ㅁ. Awareness about fuel cell is less in people

ㅁ The cost of PEM fuel cell should be reduced to 10-20 times to market it.

․ The PEM fuel cell cannot tolerate $\mathrm{CO}$, and $\mathrm{CO}$ mitigation is a problem. 


\section{Chapter 6: Hybrid System}

There are bright chances that hybrid vehicle would be a successful choice in near future. Overall efficient the hybrid systems are of great potential for coming days [12]. In hybrid electric vehicles, there is a combination of internal combustion engine of a conventional vehicle and the battery and the motor of an electric vehicle. This results in twice the fuel economy of conventional vehicles. In other words a vehicle is a hybrid when it combines two or more sources of power. An electric wheel chair is a hybrid of electricity and manual power (if motor does not work, can be pushed with hands). Many diesel electric hybrids in form of locomotives are on the move. Mining trucks and many buses are examples of diesel electric hybrid. Similarly a gasoline electric hybrid car is a combination of powers of an electric car and a gasoline car.

The combination gives the extended range and rapid refueling which consumers expect from a conventional vehicle, with a significant portion of the energy and environmental benefits of an electric vehicle. The hybrid vehicle gives improved fuel economy and lower emissions compared to conventional vehicles. Due to their propulsion system, the hybrid vehicles can be used in a wide range of applications.

Because batteries could supply only enough energy for short trips, an onboard generator powered by an internal combustion engine could be installed and used for longer trips. Therefore hybrid power system came into being to compensate the shortfall of battery technology. Before the concept of hybrid electric systems, it was thought that the working of the battery would be improved so that it could be used on longer trips but after many years of study, it seems that hybrids are taking prominent place in the market of automobiles.

Hybrid systems can never be zero emission vehicles if internal combustion engine is used in these systems, which produce air pollutants. It is hoped that the production of hybrid systems can cut emission of global warming pollutants by a third to half or more.

Following are the main features of hybrid vehicle system:

\subsection{Electric motor}

In a hybrid vehicle the electric motor is very sophisticated. It can be used as a motor as well as 
generator. When the vehicle gets accelerated, the motor acts as a motor and draws energy from the batteries of the car but when the vehicle slows down then the motor becomes a generator and supplies energy to batteries. In this case instead of just using the brakes to stop the vehicle, the electric motor that drives the hybrid vehicle can also slow the vehicle. In this situation the electric motor acts as a generator and charges the batteries while the vehicle is slowing down.

\subsection{Generator}

A generator generates electric power. It is similar to motor in construction. It is used in series hybrids mostly.

\subsection{Gasoline engine}

The construction of an engine in a hybrid car is similar to conventional cars but the size is smaller. Advanced technologies are used to reduce emissions. There are several reasons why the smaller engines are more efficient than big engines:

a Big engine is heavier than the small engine, so the car uses extra energy every time it accelerates.

a The pistons and other internal comments are heavier, which require more energy each time they go up and down the cylinder.

口 The displacement of the cylinder is larger so each cylinder requires more fuel.

口 Bigger engines usually have more cylinders, and each cylinder uses fuel every time the engine fires.

\subsection{Fuel tank}

The energy storage device for gasoline engine of the hybrid car is a fuel tank. Gasoline has much higher energy density than batteries. 


\subsection{Batteries}

The energy of an electric motor is stored in the batteries of a hybrid vehicle system. The electric motor draws energy from the batteries while the vehicle accelerates and gives energy to the batteries when slows down using brakes.

\subsection{Transmission}

The transmission of the hybrid car can be:
口 Conventional transmission
口 Advanced transmission

\subsection{Hybrid configuration}

There are two types of configurations as shown in figure 6 and 7:

口 Hybrid parallel configuration

口 Hybrid series configuration

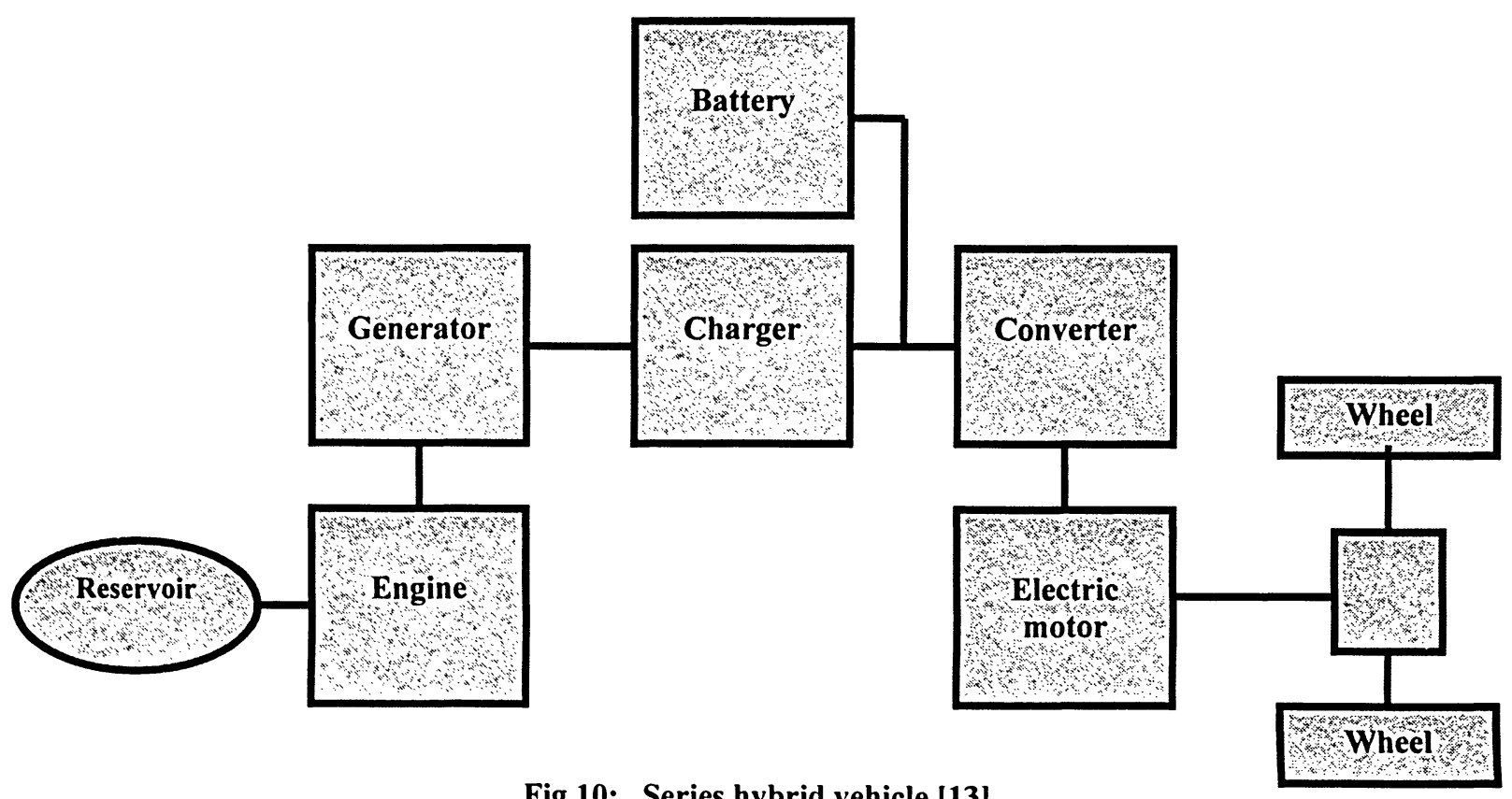

Fig 10: Series hybrid vehicle [13] 


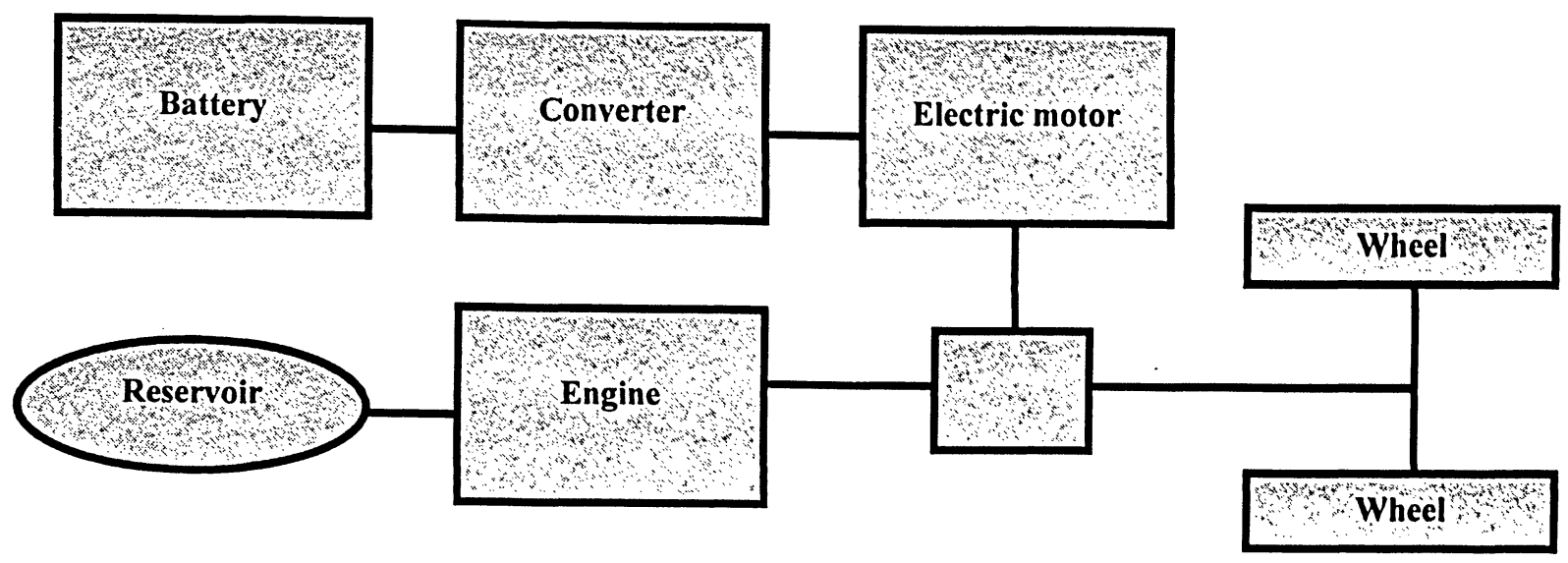

Fig 11: Parallel hybrid vehicle [13]

In a series hybrid electric vehicle, a small fuel-burning engine directly drives an alternator to generate electricity. The electricity is then stored in the batteries or sent to the electric motor, which then powers the wheels. The vehicle can operate in zero-emissions mode, and when the batteries are drained to a certain level, the engine turns on and begins to recharge them. Since it is less dependent on the vehicle's changing power demands, the engine can operate within a narrower and more efficient range of speeds.

A parallel hybrid electric vehicle is configured with two power paths, so that either the hybrid power engine or the electric propulsion system or both can be used to produce the motive power to turn the wheels. In one approach, the electric-only mode can be used for short trips. For longer trips, the engine would provide primary power to the vehicle, with the electric motor assisting during hill climb, fast acceleration, and other periods of high power demand. In such a vehicle, the engine can be downsized in relation to a similar-sized conventional vehicle, reducing weight and providing greater relative fuel economy.

The battery of the hybrid system provides power during peak power demand. The peak power time may include when the vehicle accelerates, runs at a constant high speed [14]. The study of Gutman [2] reveals that from emission view point the series hybrid vehicle is better while the parallel hybrid vehicle is better for fuel consumption. The series hybrid system can easily optimize the driving range. In parallel hybrid system the engine's force is applied to move the 
vehicle directly [4]. A series hybrid vehicle is on road in London U.K. with the name of Zevco London Taxi. A battery drives this vehicle and the battery is charged with a fuel cell [15]. If fuel cell is used instead of a combustion engine, then the emission could be reduced to a great extent. The environmental cost and energy cost would be lowered if the hybrid vehicles were used in future. The only initial cost of the vehicle is a hurdle these days [1].

\subsection{Hybrid electric system's features}

The hybrid technology would be of great importance in coming days since ICE and fuel cell both can be used in this system. When the hybrid electric vehicles are compared with conventional vehicles, the following features carı be noted:

- Engines of the hybrid electric vehicles can be sized to accommodate different loads.

a Regenerative braking is very useful feature in hybrid electric vehicles. The motor acts as a generator when the vehicle slow downs thus energy is provided to the batteries of the vehicle.

व Hybrid electric vehicles consume less fuel than vehicles powered by gasoline alone. So fuel efficiency is increased.

- The use of smaller internal combustion engines leads to fewer emissions of air pollutants and other emissions. Thus the use of hybrid electric system reduces the unwanted emissions.

- An internal combustion engine is run by the fossil fuels so use of small engine leads to less dependency on fossil fuels.

a Special lightweight materials are used to reduce the overall vehicle weight of hybrid electric vehicle.

Since it is still believed that the best way to power the vehicle is the direct hydrogen induction in the fuel cell without using a processor so hybrid vehicles could pose a threat to environment if processor is used in the fuel cell technology or if internal combustion engine is used in hybrid system [3]. 
These vehicles reduce fuel consumption.

a High power batteries give power to energy ratio $>20$ on charge and discharge.

口 High power battery assist engine during acceleration and high speed cruise.

口 Daimler-Benz has developed a car that covers $400 \mathrm{~km}$ using 38 liters of methanol.

a Smaller engine of hybrid vehicle uses less gasoline causing less emission.

․ Hybrids of ICE and electric motor are interim solution to the oil crisis and the environmental damage.

․ The permanent solution to oil crisis and environmental damage is a reformerindependent, on-board hydrogen carrier, PEM fuel cell electric vehicle.

\section{Cons}

․ Hybrid system still needs more development

a The use of internal combustion engine in a hybrid vehicle leads to dependency on oil and environmental damage. 


\section{Chapter 7: Electric Propulsion System}

An electric propulsion system is used to power an electric vehicle. The battery is the only source of power and is recharged by a power grid. A lot of advances to improve the battery of an electric vehicle have been made. One of the battery driven cars can travel up to $200 \mathrm{~km}$ on a single charge.

The simplest form of an electric propulsion system contains:

$\begin{array}{ll}\square & \text { Battery } \\ \square & \text { Converter } \\ \square & \text { Motor } \\ \square & \text { Gear arrangement }\end{array}$

The following figure 8 shows one motor drive for an electric vehicle.

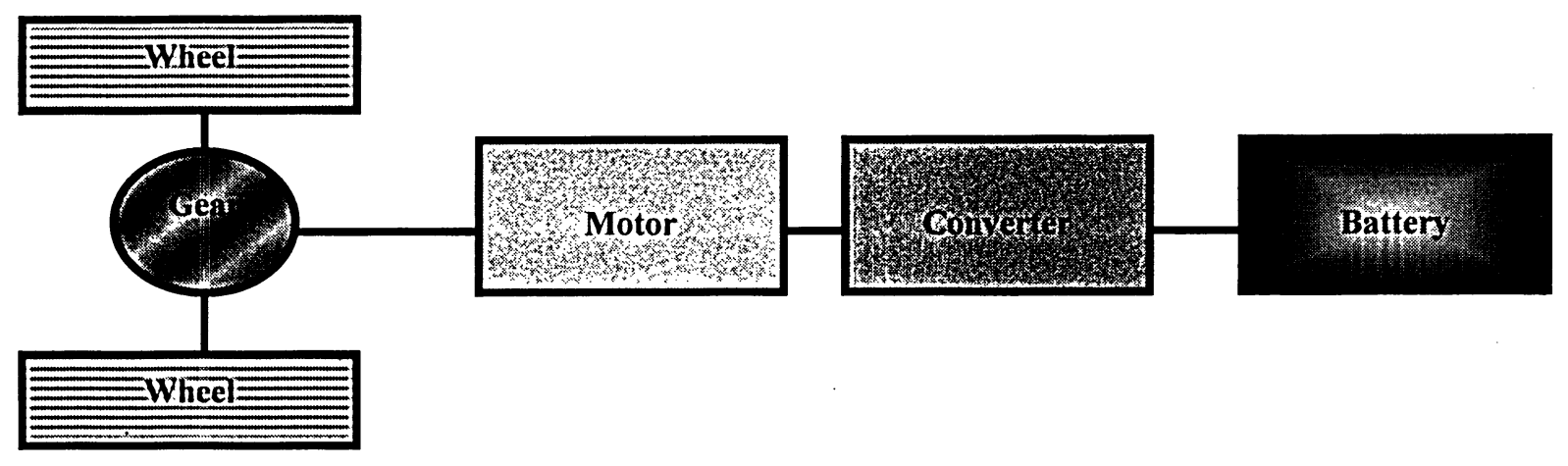

Fig 12: One motor drive for an electric vehicle [13]

The figure illustrates that energy stored in a battery is supplied to a motor through a converter. Then the motor rotates the wheel through a gear arrangement. Any significant progress has not been made during last 25 year in the area of electric vehicles. Some battery systems have doubled the range of vehicles [15].

In latest technology the electric motors are fitted in the four wheels of a vehicle and the technology is called M-4 technology. This is a successful step to eliminate the expensive mechanical components and linkages in transmission system of a vehicle [16]. The following figure 9 shows the simplest arrangement of power in a M-4 technology. 


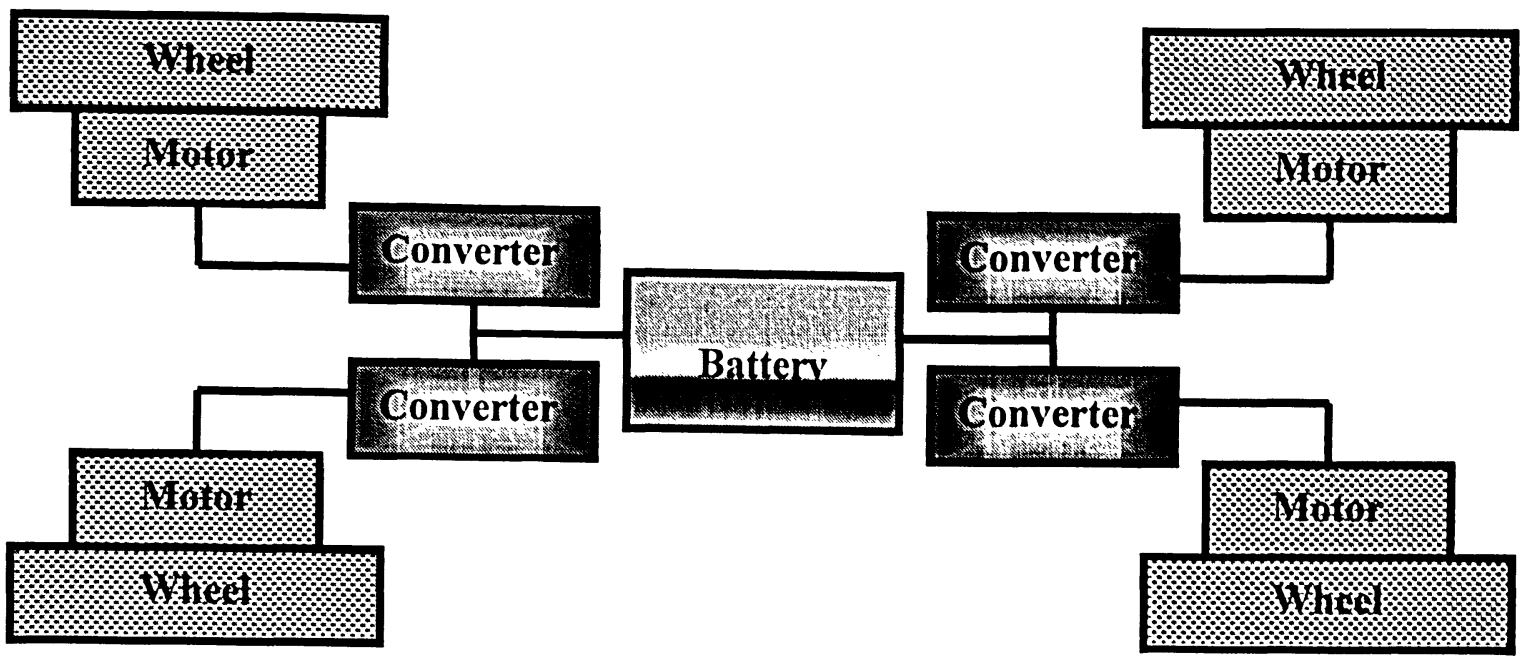

Fig 13: M-4 Technology for an electric vehicle

The electric vehicle could be a good choice for low load conditions and it does not emit pollutants. These are the disadvantages [4].

1. Long time is needed to recharge the battery

2. Short cruises distance

3. Lack of support infrastructure

4. More and bigger batteries are needed to extend the range which results in more power consumption, more vehicle weight and poor driving performance

5. Expensive batteries

The first battery was demonstrated around 200 years ago and batteries have been extensively researched since then. New battery types and significant improvements in the performance of existing batteries have prompted the increased use of batteries in our society.

The lead/acid battery is considered as transitional battery to Nickel Metal Hydride (NiMH) but the cost of the latter would be too high to market the battery [1].

The lead-acid battery is the best known and is heavy but cheap. Nickel-cadmium battery has a high power density. Sodium-Nickel chloride battery works on $270^{\circ} \mathrm{C}$ hot temperature. It is also called ZEBRA battery. This battery is considered best one for use in EV. The following table shows the characteristics of batteries for electric vehicles. Some batteries given in the following table 1 are available and some are expected to be marketed soon: 
Table 1: Characteristics of different batteries [13]

\begin{tabular}{|c|c|c|c|c|c|}
\hline & $\mathbf{P b}^{-} \mathbf{P b O}$ & $\mathrm{Ni}-\mathrm{Cd}$ & $\mathrm{Ni}-\mathrm{MH}$ & $\mathrm{Na}-\mathrm{NiCl}$ & Li-ion \\
\hline $\begin{array}{l}\text { Working } \\
\text { Temperature } \\
{ }^{2} \text { C }\end{array}$ & -20 to +60 & -40 to +60 & -40 to +50 & $300-350$ & -40 to +60 \\
\hline $\begin{array}{l}\text { Specific Energy } \\
\text { Wh/kg } \\
\text { Why }\end{array}$ & 161 & 236 & 300 & 794 & 275 \\
\hline $\begin{array}{l}\text { Specific Energy } \\
\text { 2 h discharge } \\
\text { Wh/kg } \\
\text { hh }\end{array}$ & $20-30$ & $40-55$ & $50-60$ & $80-100$ & $90-140$ \\
\hline $\begin{array}{l}\text { Energy Density } \\
\text { W/kg }\end{array}$ & $60-80$ & $60-90$ & $100-150$ & $110-120$ & $150-200$ \\
\hline $\begin{array}{l}\text { Specific Power } \\
\text { W/kg }\end{array}$ & $75-100$ & $120-150$ & $140-200$ & $150-200$ & $350-400$ \\
\hline $\begin{array}{l}\text { Cell Voltage } \\
\mathrm{V} / \mathrm{V} \text { (charged) }\end{array}$ & 2.1 & 1.35 & 1.35 & 2.58 & 3.6 \\
\hline Lifecycle & 500 & 2000 & 1000 & 1000 & 1000 \\
\hline
\end{tabular}

New resources to produce electricity should be explored to run the electric vehicles. More the electric vehicles are, more electricity to recharge their batteries is needed. The present electricity cannot meet this demand. Solar power, wind power and biomass power would have to be explored at a faster pace to bring the dream of zero emission from tail pipe true.

The electric vehicles could be effective for power load leveling under certain regulations but if there are no regulations then the on both daytime and nighttime the shortage of power will take place [17].

The use of electric vehicle reduces the emissions of $\mathrm{CO}, \mathrm{HC}$ and $\mathrm{NO}_{\mathrm{x}}$ but on the other hand due to increase in demand of electric power generation through coal-fired utilities, the emission of $\mathrm{NO}_{x}$ increases [18]. 
In early1990s, legislation was introduced for zero emission vehicles. The purpose was to use electric vehicles in California [5]. This shows that efforts to get rid of pollution have been made for many years.

Following are the pros and cons for electric vehicle:

Pros

․ No tail pipe emissions

口 No noise like internal combustion engine

․ No vibrations like internal combustion engine

- If production of electricity increases significantly, then they could be marketed easily provided battery helps extend the range.

- They are very successful for limited ranges and in quite atmospheres like hospitals etc.

\section{Cons}

口 Shorter range as compared to hybrid vehicle and internal combustion engine

․ Limited applications

口 Vehicles are costly. People would not buy expensive vehicles.

- Long charging time

口 Battery replacement is a nuisance

口 Charges for batteries are high

口 Batteries are heavy.

- Development of batteries have yet not shown considerable achievements

口 Proper dumping of non recyclable material of batteries is needed 


\section{Chapter 8: Discussion and Conclusion}

Internal combustion engines are popular due to their long range and storing oil on board could further increase the range. Owing to a well-established infrastructure, gasoline and diesel are easily available. The transportation of the fuel is not a problem. Exploration is being carried out to discover new stocks of the fuel. People are used to gasoline and diesel since their childhood and are comfortable with its safe use. Gasoline causes vomiting if it enters the human body by mistake. As the technology of ICE is very old, so skilled labor and experts are in abundance for this technology. Storage and transportation of oil are easy. A lot of money and other resources have been invested from design to manufacturing of ICE and from production to storage of oil. No doubt the price of oil is increasing day by day but still it is within the reach of the common person.

Research is being carried out and it hoped that energy and environmental cost would be reduced by $50 \%$. As the refueling, maintenance infrastructure, cost, cruising distance in other propulsion technologies create uncertainty, so it is predicted that in near the future, the ICE would not be replaced completely. ICE has a prominent place in hybrid vehicles and efforts to reduce the weight by $40 \%$ of ICE vehicles are in progress. Catalyst converter has played an important role to reduce emissions of pollutants like $\mathrm{CO}, \mathrm{HC}$, and $\mathrm{NOx}$. Still $\mathrm{NO}_{\mathrm{x}}$ is a problem for ICE. These emissions are a threat to the environment as they are the biggest cause of pollution, global warming and a health hazard. In spite of the use of a catalyst converter, the emissions are still dangerous and they need to be eliminated to save the earth. ICE vehicles produce noise and vibration. ICE is complex in construction and composed of many parts. The vehicles using ICEs can use only $12 \%$ of engine power for their propulsion, which makes ICE less efficient. The manufacturing of ICE involves much more resources like labor, materials, assembly plants as compared to fuel cell and electric motor. The import of oil is harmful for the economy. The world has reached the threshold of war due to conflicts about oil. It is desirable that switching to other resources and technologies of vehicular propulsion should be done.

Fuel cells are quiet, clean and operate as long as the fuel is supplied. They produce water and heat generating electricity, so no emissions come out of fuel cell. The fuel cells that use a reformer do produce emissions but these emissions are far less as compared to ICE's 
emissions. The fuel cells have better efficiency and performance than ICE. As the structure of a fuel cell is simpler so fewer resources like labor, vendors, manufacturing facilities etc. are needed to manufacture them. Different fuels like gasoline, methanol, ethanol, natural gas and hydrogen are available for fuel cells. Electrolysis of water produces hydrogen. DMFC does not have a reformer, so it does not creates emissions. Fuel cells are being developed for light as well as heavy-duty vehicles. PEMFC and DMFC are considered better fuel cells for transportation purposes. Ballard in Berlin has installed a PEMFC of a capacity of $200 \mathrm{~kW}$. This gives an idea to produce electricity from fuel cells with low emissions and then use that electricity for electrolysis of water to generate hydrogen. PEMFC is preferred due to its high power density of $1.35 \mathrm{~kW} /$ liter, rapid start up, variable power output, and small size. Fuel cells can be used for fleet of off-road locomotives thus the problem of accommodation of heavy container of hydrogen can be resolved. DMFC is also considered but it is inferior to PEMFC in a sense that it has less power density and problem with the membrane used in the cell. Further development is needed in fuel cell technology. Although six types of fuel cell have been developed but none of them is completely suitable for transportation. There is no infrastructure for fuel cell. Fuel, fuel sources and cost need to be addressed. Development for low cost membrane, low cost catalyst and water management is desirable. Price of PEMFC should be reduced by 10-20 times. Reformer of a fuel cell is a source of pollution so it must be removed to save the environment.

As far as hydrogen is concerned, it is the ideal fuel for fuel cell. It can be produced by electrolysis of water and by reforming of natural gas. As hydrogen is a gas with normal temperature and pressure, it poses a great threat as far as its storage and transportation are concerned. Hydrogen can be stored in gaseous form, liquid form and in the bonding of metal and hydrogen i.e. hydride form. To store hydrogen in gaseous form, a very heavy and strong steel tank is needed which eventually would reduce the performance of the vehicle. Liquid hydrogen can be stored at $-248^{\circ} \mathrm{C}$ but this storage is costly and unsafe.

Hybrid systems are acceptable at present as they offer long term and short term solutions. Different hybrid systems are present with different configuration. It is concluded that among four vehicular power systems i.e. ICE, fuel cell, hybrid system and electric system, a vehicle driven by hybrid power system consisted of a combination of Proton Exchange Membrane Fuel Cell (PEMFC) and a battery can be used as an interim step to save the environment as this 
system produces less emissions as compared to ICE. But the final and a long-term solution to the problem of emissions of pollutants and oil crisis is a hybrid vehicle that contains a reformer-independent PEM fuel cell and a battery, and has on-board pure hydrogen as a fuel. The hydrogen to be used in the fuel cell electric vehicle must be obtained from electrolysis of water using electricity generated by solar, wind or hydro resources. 


\section{References}

[1] Bengt Johansson, Max $A^{\circ}$ hman, "A comparison of technologies for carbon-neutral passenger transport", Transportation Research Part D 7 (2002) 175-196.

[2] Gunter Gutmann, Journal of Power Sources 84 (1999) 275-279

[3] B. D. McNicol, D.A.J. Rand. K.R. Williams, "Fuel Cells for Road Transportation purposesYes or No?", Journal of Power Sources 100 (2001) 47-59.

[4] Kenji Morita, "Automotive Power Source in $21^{\text {st }}$ Century", J. SAE Review 24 (2003) 3 - 7.

[5] Robert J. Farrauto, Ronald M. Heck, "Catalytic Converters: State of the Art and Perspectives", Catalysis Today 51 (1999) 351-360.

[6] Michael W. Ellis, Michael R. Von Spakovsky, Douglas J. Nelson, "Fuel Cell Systems: Efficient, Flexible Energy Conversion for the $21^{\text {st }}$ Century", Proceedings of the IEEE, Vol. 89, NO. 12, December 2001

[7] Ali T-Raissi, Arundhati Banerjee, Kenneth G. Sheinkopf, Florida Solar Energy Center 1679 Clearlake Road Cocoa, Florida 32922.

[8] Fari Ordubadi, Ballard Generation systems, "PEM Fuel Cells and Future Opportunities", 07803-7173/01 @ IEEE

[9] Ali T-Raissi, Arundhati Banerjee, Kenneth G. Sheinkopf, "Metal Hydride Storage Requirements For Transportation Applications" 0-7803-3547-3-7/16 \ 1996 IEEE

[10] Bernd Kohlstruck, Alstom Ballard GmbH, "Applications with Proton Exchange Membrane Fuel Cells for a Deregulated market Place", CIRED2001, 18-21 June 2001, Conference Publication No. 482 @ IEE 2001

[11] Donald MacArthur, "Fuel Cells for Electric Vehicles: Issues and Progress", 0-7803-4967$9 / 99$ @ 1999 IEEE

[12] Nobuo Iwai, "Analysis on Fuel Economy and Advanced Systems of Hybrid Vehicles", JSAE Review 20 (1999) 3-11

[13] Gaston Maggetto, Joeri Van Mierlo, "Electric Vehicles, Hybrid Electric Vehicles and Fuel Cell Electric Vehicles: State of the Art and Perspectives", Ann. Chim. Sci. Mat, 2001, 26 (4), PP 9-26

[14] M. Nadal, F. Barbir, "Development of a Hybrid Fuel Cell/ Battery Powered Electric Vehicle", Int. J. Hydrogen Energy Vol. 21, No. 6, pp. 497-505, 1996 
[15] G.G. Harding, "Electric Vehicles in the Next Millennium", Journal of Power Sources 78 (1999) 193-198

[16] S. Gair, Napier University Department of EEE U.K., E-mail: $\underline{\text { s.gair@napier.ca.uk }}$

[17] Fumiko Koyanagi, Yoshihisa Uriu, "Modeling Power Consumption by Electric Vehicles and Its Impact on Power Demand", Electrical Engineering in Japan, Vol. 120, No. 4, 1997

[18] Burns, Robert Thomas (1996), PhD., The University of Tennessee, "The Impact of Electric Vehicles on Ozone Formation in the Middles Tennessee Area", Order Number DA 9609340

[19] Tom Gilchrist (1998), Ballard Power Systems Inc., IEEE Spectrum.

[20] J. Fernando Contadini (2000), "Social Cost Comparison Among Fuel Cell Vehicle Alternatives", The American Institute of Aeronautics and Astronautics, Inc.

21. Willard W. Pulkrabek, "Engineering Fundamentals of the Internal Combustion Engine", Prentice-Hall Inc., NJ, 1997

22. W. J. D. Annad, M. L. Monghan etc, "Internal Combustion Engines", Academic Press Toronto, 1988

23. Colin R. Ferguson, "Internal Combustion Engines: Applied Thermodynamics", Johan Wiley \& Sons Toronto, 1986

24. William H. Crouse, "Small Engine Mechanics", McGraw-Hill Inc., U.S.A, 1980

25. L. J. Reid, "Small Engines", McGraw-Hill Ryerson Limited Toronto, 1972

26. Dr. H. Schwarz, W. Dieter, E. Wild etc., "Gasoline-Engine Management”, Robert Bosch GmbH Germany, 1999 